\title{
A density-dependent multi-species model to assess groundwater flow and nutrient transport in the coastal Keauhou aquifer, Hawai'i, USA
}

\author{
Brytne K. Okuhata ${ }^{1}$ (D) Aly I. El-Kadi ${ }^{1,2} \cdot$ Henrietta Dulai ${ }^{1,2} \cdot$ Jonghyun Lee ${ }^{2,3} \cdot$ Christopher A. Wada $^{2,4}$. \\ Leah L. Bremer ${ }^{2,4} \cdot$ Kimberly M. Burnett ${ }^{2,4}$ - Jade M. S. Delevaux ${ }^{5} \cdot$ Christopher K. Shuler $^{2}$
}

Received: 25 January 2021 / Accepted: 11 September 2021 / Published online: 8 October 2021

(C) The Author(s) 2021

\begin{abstract}
Fresh groundwater is a critical resource supporting coastal ecosystems that rely on low-salinity, nutrient-rich groundwater discharge. This resource, however, is subject to contamination from point- and nonpoint-sources such as on-site sewage disposal systems (OSDS) and urban developments. Thus, the significance of flow and transport processes near the coastline due to density effects and water circulation in a complex hydrogeologic system was investigated. A three-dimensional, density-dependent groundwater model was developed for the Keauhou basal aquifer (Hawai'i Island, USA), where hydraulic head, salinity, nutrient concentrations, and submarine spring flux rates were used as calibration variables to best constrain parameters and produce a comprehensive aquifer management tool. In contrast, a freshwater-only model failed to properly simulate nutrient transport, despite the reasonable success in calibrating hydraulic head measurements. An unrealistic value for hydraulic conductivity was necessary for freshwater-only calibration, proving that hydraulic conductivity is a process-based variable (i.e., depends on model conceptualization and the simulated processes). The density-dependent model was applied to assess relative contaminant source contributions, and to evaluate aquifer response concerning water levels and quality due to changing environmental conditions. Nutrients detected in the aquifer are primarily sourced from OSDS, which was supported by a nitrogen isotope mixing model. Additionally, effects of sea-level rise emphasized the complexity of the study site and the importance of model boundaries. While the model is developed and applied for West Hawai' $i$, the adapted approaches and procedures and research findings are applicable to other coastal aquifers.
\end{abstract}

Keywords Numerical modeling $\cdot$ Coastal aquifer $\cdot$ Nutrient transport $\cdot$ Aquifer management $\cdot$ USA

Brytne K. Okuhata

bokuhata@hawaii.edu

1 Department of Earth Sciences, University of Hawai'i at Mānoa, Honolulu, HI 96822, USA

2 Water Resources Research Center, University of Hawai'i at Mānoa, Honolulu, HI 96822, USA

3 Department of Civil and Environmental Engineering, University of Hawai`i at Mānoa, Honolulu, HI 96822, USA

4 University of Hawai'i Economic Research Organization, Honolulu, HI 96822, USA

5 The Natural Capital Project, Stanford University, Stanford, California 94305-5020, USA

\section{Introduction}

Groundwater is a critical natural resource required for daily human use such as potable water supply, industrial uses, and agricultural irrigation (Kemper 2004; Alley 2006). The Keauhou region, located on the west side of Hawai' $i$ Island (USA), has approximately $97 \%$ of its freshwater demand supplied by groundwater resources pumped from the Keauhou aquifer system (Fukunaga 2017). As Hawai'i's population increases, future land development and higher water demand are inevitable, along with an expected overall decline in recharge rates due to projected climate change conditions (Elison-Timm et al. 2015). These combined factors will further exacerbate saltwater intrusion (Ferguson and Gleeson 2012), thus emphasizing the need to understand how future circumstances may affect groundwater resources. 
Additionally, submarine groundwater discharge (SGD) transports human-derived nutrients to the coast, discharging as point sources (submarine springs) or non-point seepage (diffuse) sources (e.g., Burnett et al. 2003; Moore 2010; Parra et al. 2014). Natural and anthropogenically derived nutrients such as nitrate $\left(\mathrm{NO}_{3}{ }^{-}\right)$and phosphate $\left(\mathrm{PO}_{4}{ }^{3-}\right)$, have the potential to negatively impact drinking water and the biota of coastal ecosystems, which serve as important environmental, economic, food, and cultural resources (Duarte et al. 2010). Excess nutrients often originate from different types of land use and land cover (LULC) and wastewater infrastructuree.g., on-site sewage disposal systems (OSDS); e.g., Knee et al. (2010); Shuler et al. (2017); Delevaux et al. (2018). Hawai' ${ }^{i}$ encompasses several types of LULC, including natural, agricultural, and varying degrees of urbanization (Whittier and ElKadi 2014). Continuous urban, suburban, rural housing and commercial development alters groundwater quality through wastewater and landscape runoff and is of growing concern, especially where groundwater directly discharges to coastal waters (Knee et al. 2010). In many coastal areas, OSDS associated with development are considered one of the major sources of nutrient contamination (e.g., Lapointe et al. 1990; Harris 1995; Reay 2004). The majority of these OSDS are cesspools, where wastewater effluent is not treated before entering the groundwater system (Whittier and El-Kadi 2014). Most of Hawai'i's OSDS are located near the shoreline (Whittier and El-Kadi 2014), and hence overlooking freshwater-saltwater interactions can lead to inaccurate interpretations of resulting contaminant loads and consequently poorly inform water management decisions.

Multiple studies across Hawai' $i$ demonstrated that elevated nitrogen is the most common coastal water impairment problem (Howarth and Marino 2006). Excess amounts of nutrients such as $\mathrm{NO}_{3}{ }^{-}$, are of primary concern because they can have negative impacts on human health and can significantly affect coastal ecosystem productivity and health (Kendall and Aravena 2000; Duarte et al. 2010). Besides natural sources and agricultural and lawn runoff, wastewater is the most frequently implicated source of excessive nitrogen (Knee et al. 2008; Street et al. 2008). Stable isotopes of nitrate $\left(\delta^{15} \mathrm{~N}\right.$ and $\delta^{18} \mathrm{O}$ of $\mathrm{NO}_{3}{ }^{-}$) are commonly used to distinguish nitrogen derived from various sources (e.g., Kendall and Aravena 2000). It can sometimes be difficult, however, to identify the exact nitrogen source due to the wide range and overlapping nature of these isotopic endmembers. An integrative, modelbased approach can quantify relative nutrient contributions from various sources and identify essential areas of remediation for resource managers (e.g., Shuler et al. 2017).

Water resource managers often turn to numerical models to better understand the groundwater system and predict how aquifers will respond to future climate and LULC scenarios. Outside of Hawai' $i$, various numerical models have been developed to investigate groundwater contamination from
LULC and OSDS in coastal aquifer systems using a freshwater-only approach (e.g., Pang et al. 2006; Shuler et al. 2017; Walter 2008) and a density-dependent approach (El-Kadi et al. 2014; Murgulet and Tick 2016). Generally, groundwater flow and contamination in Hawai' $i$ are studied using the US Geological Survey (USGS) suite of models (US Geological Survey 2021; El-Kadi and Moncur 2006). Unfortunately, there are only a few Hawai'i-based models developed to investigate LULC and OSDS contamination. Delevaux et al. (2018) and Amato et al. (2020) developed freshwater models to examine LULC and OSDS-derived contamination transport, while Habel et al. (2017) examined groundwater inundation as a result of sea level rise. In comparison, studies such as Voss and Souza $(1987,1998)$ and Gingerich and Voss (2005), have used density-dependent models to examine the freshwater-saltwater transition zone but did not assess OSDS contamination. To avoid complications in solving nonlinear equations (e.g., Holzbecher 1998) and increased data needs, current management of Hawai'i's water quality relies on a freshwater-only modeling approach (e.g., Whittier and El-Kadi 2014). This approach has several limiting factors, including the failure to account for (1) dynamics of the freshwater-saltwater interface and forming a brackish transition zone; (2) inland saltwater influxes required for accurate assessment of groundwater sustainability; (3) accurate parameters based on salinity measurements; (4) potential sea level rise and saltwater intrusion; and (5) an accurate flow field that controls chemical transport (Mezzacapo et al. 2020).

Based on these limiting factors, it is hypothesized that a freshwater-only model fails to properly simulate nearshore solute transport. The objective of this study was thus to investigate the significance of flow and transport processes near the coastline due to density effects and water circulation in a complex hydrogeologic system. This study aimed to ameliorate earlier model approaches and demonstrate the applicability of the model as an aquifer assessment tool. To that end, a three-dimensional (3D) density-dependent multi-species model was developed for the Keauhou basal aquifer and calibrated with all available data, including hydraulic head, salinity, submarine spring flux rates, and nutrient concentrations. To avoid overfitting, the number of calibration parameters was minimized by utilizing independently estimated values and critical input variables were investigated through sensitivity analysis. Further, $\delta^{15} \mathrm{~N}$ was used for independent model validation. The relative nutrient contributions predicted by the model were integrated with $\delta^{15} \mathrm{~N}$ measurements and an isotope mixing equation to confirm point- and non-point source contamination. A similar approach was utilized for Tutuila, another tropical volcanic island, by Shuler et al. (2017), but has not yet been done in this study area. The study also assessed suitability of a freshwater-only model in simulating the transport of nutrients in the aquifer. Finally, the density-dependent model 
was applied to test cases, specifically urban development, climate change, and sea level rise.

\section{Materials and methods}

\section{Study area}

Hawai' $i$ Island is the largest island $\left(10,464 \mathrm{~km}^{2}\right)$ in the Hawaiian archipelago and was built by five shield volcanoes: Kohala, Mauna Kea, Hualālai, Mauna Loa, and Kîlauea (Izuka 2011). Basaltic lava flows from these five volcanoes covered the island's surface less than 1 million years ago, making Hawai' $i$ Island the youngest island in the chain (Clague and Dalrymple 1987). The eruption of each volcano was partially simultaneous with its neighboring volcano, so it is likely that lava flows from neighboring volcanoes interfinger with each other, creating complex geologic contacts (Wolfe et al. 1997; Izuka et al. 2018). Basaltic lava typically flows as either pāhoehoe or 'a'ā, which differ in viscosity and texture (e.g., DePaolo and Stolper 1996; Lau and Mink 2006; Izuka et al. 2018). For sequences of pāhoehoe, groundwater primarily travels through spaces, tubes, and vesicles that are formed between the multiple layers of lava flows, resulting in higher porosity and permeability. 'A $A \bar{a}$ are comprised of two general components-clinker beds and massive cores. The ' $a$ 'a clinker beds typically demonstrate higher porosity and permeability while the dense ' $a$ ' $\bar{a}$ cores demonstrate lower porosity and permeability and thus impede groundwater flow across layers (Izuka et al. 2018). Because it is common to see alternating pāhoehoe and ' $a$ 'a $\mathrm{a}$ flows in cross section, the hydrogeologic parameters typically represent both flow types (Lau and Mink 2006).

Located in the northern Kona district, the southern flank of Hualālai is defined as the Keauhou aquifer $\left(426 \mathrm{~km}^{2}\right.$; Fig. 1). The Keauhou aquifer is geologically divided into a basal aquifer and a high-level aquifer with a discontinuous head profile characterized by a near abrupt change. Water levels near the coast are approximately $1 \mathrm{~m}$ above mean sea level (msl) but dramatically rise to more than $100 \mathrm{~m}$ above msl approximately 4-8 km inland (Fig. 1). It is believed that a subsurface geologic structure reduces groundwater flow from the high-level aquifer to the coast (Oki 1999). Efforts to characterize this structure include modeling of gravity survey data that indicate the presence of a dense substructure under Hualālai, located approximately $4 \mathrm{~km}$ southwest of the eruptive vents that map Hualālai's southeast rift zone (Kauahikaua et al. 2000; Flinders et al. 2013). Although the geologic structure has been conceptually hypothesized (Oki 1999, their Fig. 6), the exact nature of the structure is still not well defined, which is beyond the scope of this study. Another significant, yet undefined, geologic feature acts as a confining unit, creating a second, deep freshwater body below the primary basal aquifer (Thomas et al. 1996; Attias et al. 2020). Since this study focuses on the shallow groundwater, however, no attempt was made to simulate such a feature. To avoid such uncertainties, this study instead focuses on the Keauhou basal aquifer $\left(150 \mathrm{~km}^{2}\right)$, with head levels less than $5 \mathrm{~m}$ and the eastern boundary coinciding with the geologic structure bordering the high-level aquifer (Fig. 1). The western boundary follows bathymetry and extends beyond the coastline to accurately account for processes at the land-ocean interface.

\section{Available data}

\section{Water levels}

Considering the scarcity of current measurements and necessity of spatially distributed data, initial pre-development water levels were used in the model calibration for a total of 54 measurements. Static, initial water levels (one per well) were obtained from the Commission on Water Resource Management (CWRM), where the majority of these levels were measured at the time of drilling, which occurred between 1944 and 2008 (Fig. 2d). While water levels change over time and available values at other wells do not necessarily accurately represent current conditions, initial water level data from four monitoring wells fell within the ranges of continuous measurements sampled on a quarterly basis (Fig. S1 of the electronic supplementary material (ESM). Further, the inclusion of all initial water level measurements yielded better results with a more robust dataset.

\section{Nutrient and $\delta^{15} \mathrm{~N}$ data}

Median salinity, $\mathrm{NO}_{3}^{-}+\mathrm{NO}_{2}^{-}$and $\mathrm{PO}_{4}{ }^{3-}$ concentrations from 20 wells (Tachera 2021) were used for model calibration (Table S1.2 of the ESM). Production well samples were collected three to four times over a year, thus median values were used to represent annual concentrations. Thirteen salinity concentrations and $19 \mathrm{NO}_{3}{ }^{-}+\mathrm{NO}_{2}^{-}$and $\mathrm{PO}_{4}{ }^{3-}$ concentrations were collected at identified submarine springs by $\mathrm{H}$. Dulai (University of Hawai' 'i at Mānoa, unpublished data, 2019) and utilized in model calibration (Fig. 2d; Table S1.3 of the ESM). Hawaiian aquifers are well oxygenated, exhibiting dissolved oxygen saturations $>90 \%$ (Richardson et al. 2017). It is therefore assumed that dissolved nitrogen species quickly oxidize to $\mathrm{NO}_{3}{ }^{-}$(Whittier and El-Kadi 2009). Because $\mathrm{NO}_{3}{ }^{-}+$ $\mathrm{NO}_{2}{ }^{-}$and $\mathrm{PO}_{4}{ }^{3-}$ (further referred to as $\mathrm{N}$ and $\mathrm{P}$, respectively) were the major chemical species of nitrogen and phosphorus, these were used during model calibration. Concentrations of $\mathrm{NO}_{3}{ }^{-}$represent $>70 \%$ of $\mathrm{TN}$ in the Keauhou aquifer, thus the error introduced by using $\mathrm{NO}_{3}^{-}+\mathrm{NO}_{2}^{-}$values for model calibration is assumed to be minimal. 


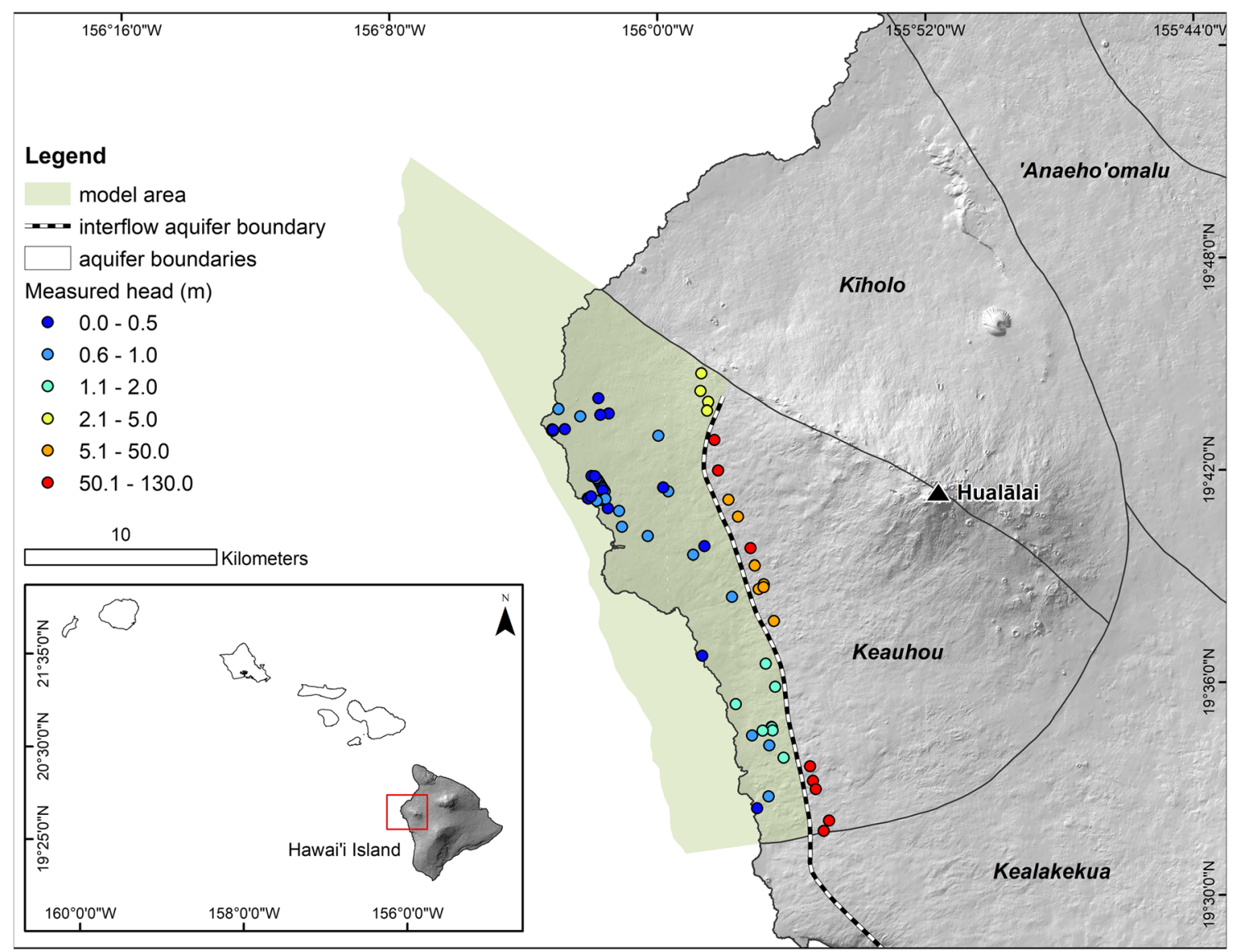

Fig. 1 Keauhou and Kîholo aquifers with volcanics flow distribution and measured water levels (Hawai'i Commission on Water Resource Management, unpublished data, 2017). The figure illustrates the boundary between the basal aquifer and high-level aquifer, which is utilized as the eastern boundary of the study area

concentration system and ThermoScientific Delta V Plus mass spectrometer (Bremen, Germany). The final $\delta^{15} \mathrm{~N}$ results were calibrated against $\mathrm{NO}_{3}{ }^{-}$standards (USGS 32, USGS 34, USGS 35) obtained from NIST (National Institute of Standards and Technology, Gaithersburg, Maryland, USA).

Submarine spring samples were collected with a 1-m stainless-steel push-point sampler (MHE Products) connected to a peristaltic pump to capture groundwater before mixing with ocean water. All submarine spring samples were filtered with $0.45-\mu \mathrm{m}$ hydrophilic polyethersulfone capsule filters at the time of sampling. Nutrient samples were analyzed for total dissolved nitrogen (TDN), total dissolved phosphorus (TDP), $\mathrm{NO}_{3}^{-}+\mathrm{NO}_{2}^{-}$(because of negligible $\mathrm{NO}_{2}^{-}$, from here on only listed as $\mathrm{NO}_{3}{ }^{-}$), $\mathrm{PO}_{4}{ }^{3-}$ (DIP), $\mathrm{NH}^{4+}$, and $\mathrm{SiO}_{4}{ }^{4-}$ (DSi) with a SEAL AutoAnalyzer $3 \mathrm{HR}$ in the S-Lab at the University of Hawai ${ }^{i}$ i, Mānoa. Sample precisions within one standard deviation based on duplicates were $0.10 \mu \mathrm{M}$ for $\mathrm{NO}_{3}{ }^{-}, 0.19 \mu \mathrm{M}$ for $\mathrm{NH}^{4+}, 0.015 \mu \mathrm{M}$ for $\mathrm{PO}_{4}{ }^{3-}$, and $2.5 \mu \mathrm{M}$ for DSi. Dissolved inorganic nitrogen (DIN) concentrations were calculated as the sum of $\mathrm{NO}_{3}{ }^{-}$and $\mathrm{NH}^{4+}$, and DON concentrations were determined by difference between TDN and DIN. 


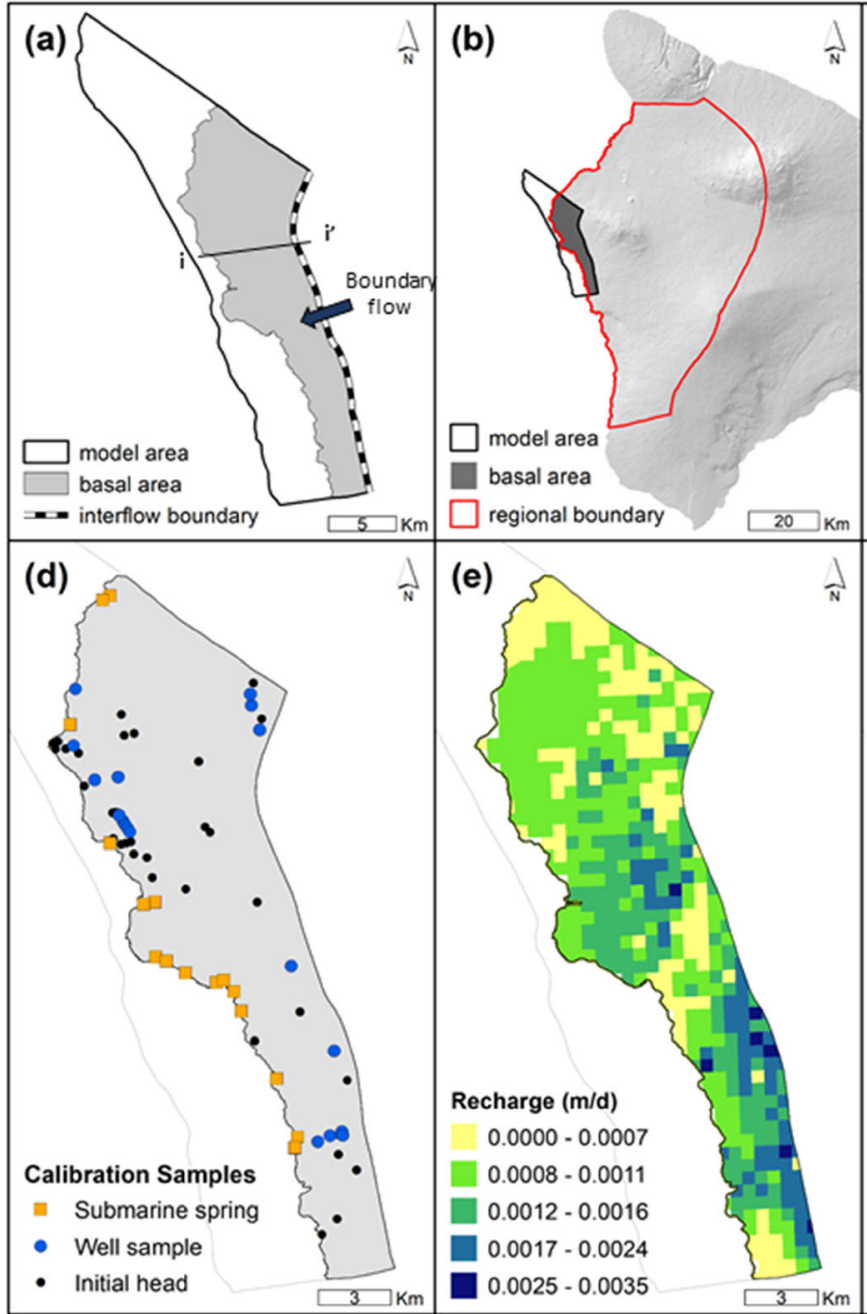

Fig. 2 Groundwater conceptual model and numerical model inputs. a Conceptualization of the Keauhou basal aquifer model. b Regional model boundary for West Hawai'i from which specified flow for the eastern boundary was estimated for the Keauhou basal aquifer model. c Vertical cross section i-i' (in part a) of the model grid with utilized boundary conditions. d Locations of wells and submarine spring measurements used for model calibration; locations of initial head

\section{Recharge, pumping rates, and submarine spring fluxes}

Spatial data assigned to the model grid are defined as geospatial coverages. Recharge data for Keauhou (Fig. 2e) were obtained from the USGS Hawai' $i$ Island water budget model, calculated for the 1984-2008 period (Engott 2011). Briefly, using a "reservoir" model, the recharge was calculated with rainfall (Giambelluca et al. 1986), fog interception (Juvik and Ekern 1978), and irrigation as inputs, and total evapotranspiration and runoff as outputs. Further, it utilized land cover from the Hawai'i Gap Analysis Program (US Geological Survey 2006) and anthropogenically sourced direct recharge - including cesspool leakage, water-main leakage, and disposal pit for treated effluent from the Kealakehe Wastewater Treatment Plant (WWTP). All pumping rates

\section{(c)}
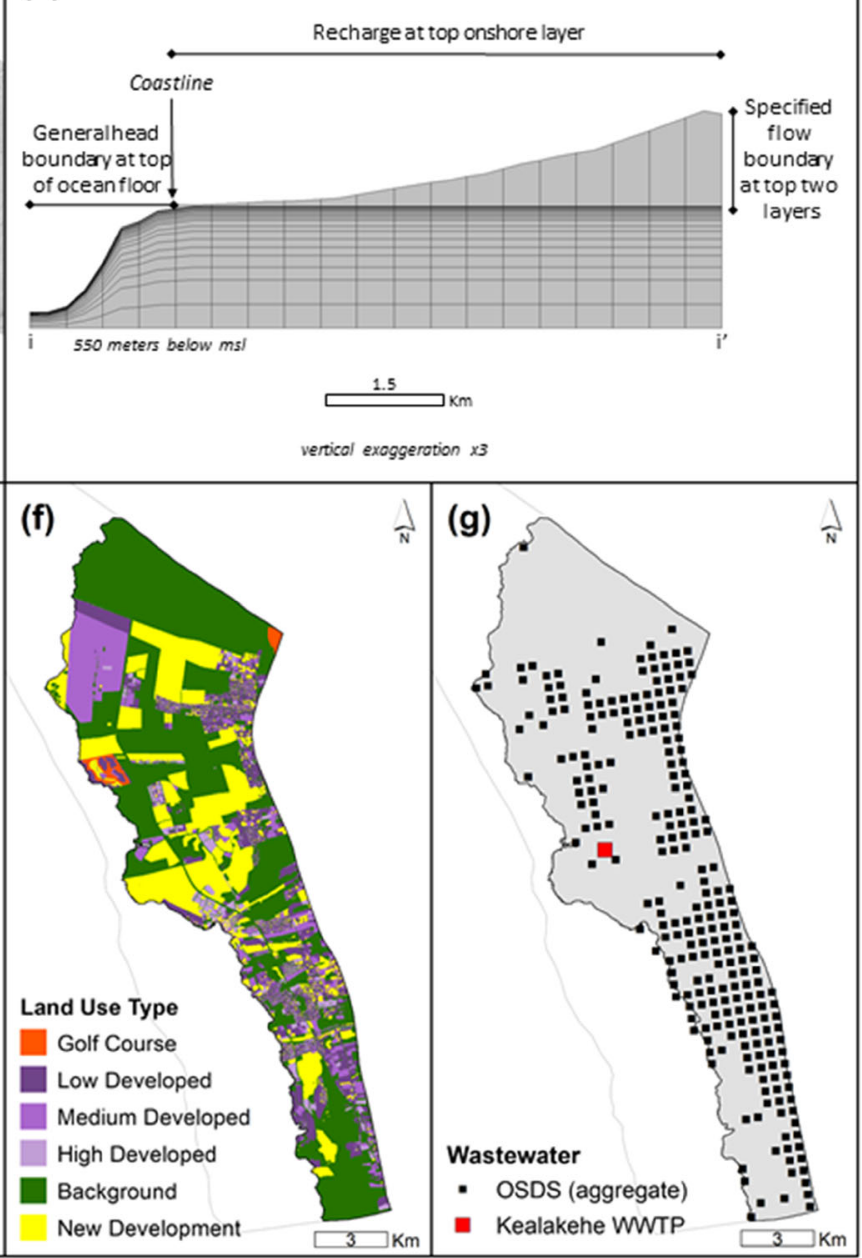

measurements used for head calibration. e Recharge spatial distribution previously calculated by Engott (2011). f Spatial distribution of land use and land cover (LULC) types assigned varying concentrations of $\mathrm{N}$ and $\mathrm{P}$ as previously determined by Delevaux et al. (2018). g Locations of aggregated on-site sewage disposal systems (OSDS) and the Kealakehe Wastewater Treatment Plant (WWTP)

documented from 1990 to 2017 were obtained from CWRM. Approximately $42,000 \mathrm{~m}^{3} /$ day of water is pumped from 28 wells located in the Keauhou basal aquifer. Johnson et al. (2008) detected at least 27 submarine spring locations along the Keauhou coastline using aerial infrared imaging and estimated the flow rate of 19 of those springs, ranging from 370 to $22,000 \mathrm{~m}^{3} /$ day.

\section{Current land use and land cover (LULC)}

In areas of urban development, this model considered LULC and OSDS as primary nutrient sources. LULC can influence the groundwater concentrations of $\mathrm{N}$ and $\mathrm{P}$ due to wastewater and nutrient inputs to lawns and agricultural systems. In this model, LULC was divided into three main 
categories: natural (background), golf courses, and urban development (Fig. 2f). Natural N and P concentrations were assigned based on average measured concentrations from pumping wells across Keauhou $(1.0$ and $0.1 \mathrm{mg} / \mathrm{L}$, respectively). Golf course locations were extracted from the Hawai'i Statewide GIS Program (State of Hawai' $i$ 2021) and assigned predetermined $\mathrm{N}$ and $\mathrm{P}$ concentrations of 7.59 and $0.54 \mathrm{mg} / \mathrm{L}$, respectively (Delevaux et al. 2018). Urban development was further divided into three levels of development intensity (low, medium, and high), as defined by the 2005 Hawai'i Coastal Change Analysis Program (National Oceanic and Atmospheric Administration 2006). In this study, urban development was defined by the land's green space. Structures associated with urban development were treated separately through calculation of nutrient inputs from OSDS. Nutrient loads associated with residential wastewater from OSDS in urban developed lands were added separately to the model as a point-source coverage - further explained in section 'Onsite sewage disposal systems (OSDS) and wastewater treatment plants (WWTP)'.

Delevaux et al. (2018) determined that the N and P concentrations leaching from a typical lawn are 0.2 and $0.01 \mathrm{mg} / \mathrm{L}$, respectively. The low, medium, and high intensity developments correspond to 65,35 , and $10 \%$ of green space per land parcel, respectively. Therefore, low intensity development areas, with a larger proportion of lawns, leach more $\mathrm{N}$ and $\mathrm{P}$ into the ground via lawn maintenance. In contrast, high intensity development areas, with a smaller proportion of lawns, leach less $\mathrm{N}$ and $\mathrm{P}$ into the ground. To account for the development intensity of each land parcel, typical lawn concentrations were scaled according to the proportion of lawns for each development intensity and added to the background concentrations (Table 1). These LULC concentrations were intersected with recharge and applied to the model.

Table 1 Annual nutrient concentrations assigned to recharge based on land cover. The current land use and land cover (LULC) designations are also shown in Fig. $2 \mathrm{f}$

\begin{tabular}{lll}
\hline Source & {$[\mathrm{N}](\mathrm{mg} / \mathrm{L})$} & {$[\mathrm{P}](\mathrm{mg} / \mathrm{L})$} \\
\hline Natural (background) $^{\prime}$ & 1.0 & 0.1 \\
Golf course $^{\mathrm{a}}$ & 7.59 & 0.54 \\
Development (low intensity) $^{\mathrm{b}}$ & 1.13 & 0.1065 \\
Development (medium intensity) $^{\mathrm{c}}$ & 1.07 & 0.1035 \\
Development (high intensity) $^{\mathrm{d}}$ & 1.02 & 0.101 \\
\hline
\end{tabular}

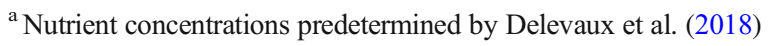

${ }^{\mathrm{b}}$ [typical lawn concentration] $\times 0.65+$ [background concentration]

${ }^{\mathrm{c}}$ [typical lawn concentration] $\times 0.35+$ [background concentration]

${ }^{\mathrm{d}}$ [typical lawn concentration] $\times 0.10+$ [background concentration]

\section{On-site sewage disposal systems (OSDS) and wastewater treatment plants (WWTP)}

The OSDS point-source coverage was obtained from a statewide OSDS census database (State of Hawai' ${ }^{\circ}$ 2021; Whittier and El-Kadi 2014). Within the study area, there are 1,094 class I (soil) units, 77 class II (septic tank to seepage pit) units, 16 class III (aerobic treatment to seepage pit) units, and 6,251 class IV (cesspool) units (Table S2 of the ESM). Nutrient mass loads for each OSDS point are reported in units of $\mathrm{kg} /$ day and were determined by applying typical nutrient concentrations to the estimated effluent rate (Table S2 of the ESM; Whittier and El-Kadi 2014). This OSDS coverage has a much finer resolution than the model grid, so to properly simulate the total (rather than average) mass load entering the groundwater system, all loads from OSDS points that fall within a single grid cell were integrated (Fig. 2g). That summed value was applied to the top layer of that respective cell in the model. With this method, 250 grid cells represent the OSDS compared to the 6,593 actual units, but the total mass load of $890 \mathrm{~kg} /$ day was maintained. The Kealakehe WWTP treats wastewater in aerated lagoons before disposing the effluent in a $930-\mathrm{m}^{2}$ disposal percolation basin (Wilson Okamoto Corporation 2019; Fig. 2g). Currently, the basin has an average flow rate of $6,435 \mathrm{~m}^{3} /$ day with $\mathrm{N}$ and $\mathrm{P}$ mass loads of 144 and $45 \mathrm{~kg} / \mathrm{day}$, respectively (Wilson Okamoto Corporation 2019).

\section{Conceptual model}

Rather than modeling the entire Keauhou aquifer, only the basal area was selected as the focus for this study (Figs. 1 and 2a) and the high-level Keauhou aquifer was excluded due to the following factors:

1. Water level observations from the high-level aquifer needed for accurate calibration are inadequate.

2. In contrast to the basal aquifer, there is less concern for increased salinity under extreme conditions due to the thick freshwater layer created by the high-level water.

3. Similarly, nutrient contamination threats are less serious than in the basal aquifer.

4. There is uncertainty regarding the inland (eastern) boundaries of the Keauhou aquifer (Fig. 1). Such boundaries are based on surficial features (Commission on Water Resource Management 2019), which do not necessarily coincide with subsurface divides. Therefore, potentially significant inter-aquifer groundwater flow may occur and thus cannot be treated as no-flow boundaries (Fackrell et al. 2020). As an additional benefit, modeling the smaller area reduces computational expenses associated with modeling density-dependent water flow and transport. 
With the exclusion of the high-level aquifer, the eastern model boundary of the basal aquifer was assigned a specified flow condition and the flow rate was estimated by creating a regional, freshwater-only MODFLOW model for West Hawai'i (Fig. 2b). Since the eastern boundary of this regional area generally follows the rift zones of Mauna Kea and Mauna Loa, groundwater is not believed to flow from the windward to leeward side of the island (Izuka et al. 2018), and thus the boundary can safely be assigned a no-flow condition. Such a regional model would eliminate the concern about interaquifer flow. The geologic structure was simulated as a horizontal flow barrier in the regional model and was reasonably calibrated to estimate hydraulic conductivity $\left(K_{\mathrm{h}}\right)$ and the barrier conductance. MODFLOW's zone-budget option was used to estimate the flow into the eastern boundary of the basal aquifer area. The flows through the northern and southern boundaries were negligible and therefore it was reasonable to treat them as no-flow boundaries.

Submarine springs are dominated by brackish spring flows along the coastline of the study site (Johnson et al. 2008; Duarte et al. 2010; Kelly et al. 2019). In contrast to diffuse SGD, these point-source springs are caused by preferential flow (Taniguchi et al. 2019). Explicitly modeling preferential flow is impractical due to the absence of detailed aquifer information, mostly related to identification of fractures or conduits contributing to preferential flow. As an approximation, springs were simulated as point drains, or head-dependent sinks, at their respective coordinate locations along the coastline. A similar approach was adopted for volcanic aquifers by Oki (2005) and El-Kadi et al. (2014). The approach is motivated by studies that indicated that discharge from springs is directly related to the aquifer's head gradient (Taniguchi et al. 2002; Duarte et al. 2010). In MODFLOW, the drain flow is estimated through Darcy's law, utilizing conductance and hydraulic head terms. In this study, with head levels roughly constant near the shoreline, it was reasonable to assume that conductance of each submarine spring was linearly proportional to the respective measured flow rate. Thus, each submarine spring point has a unique conductance value representing the varying degrees of preferential flow that can be encountered across this complex aquifer system. The bottom of the drain was assumed to be $0.5 \mathrm{~m}$ below msl, representing the rough depth from which the springs were sampled. The drains were thus located within the top layer of the model.

\section{Numerical model}

The study applied SEAWAT, a transient, multispecies density-dependent model (Langevin et al. 2008), which combines MODFLOW (Harbaugh et al. 2000) with MT3DMS (Zheng and Wang 1999). The software package interface GMS (Aquaveo 2021) was used in facilitating the modeling process. Quasi steady-state simulations were utilized by running the models for 30 years to reach near steady-state conditions. The model consists of 21 layers, 82 rows, and 36 columns (totaling 26,323 cells) and is rotated $10^{\circ}$ counterclockwise. The model grid covers the Keauhou basal aquifer and extends out into the ocean. The grid's top elevation follows topography and bathymetry and the bottom of the grid has a flat elevation of $550 \mathrm{~m}$ below msl (Fig. 2c). With head levels less than $5 \mathrm{~m}$ above $\mathrm{msl}$, and assuming validity of the GhybenHerzberg relation, the freshwater-saltwater interface is expected to be located approximately $200 \mathrm{~m}$ below msl. The additional model depth was included as a buffer to ensure the flow in the model area is not significantly affected by the bottom boundary condition. Because the bathymetry offshore of Keauhou is highly variable, the model grid extends perpendicularly offshore as far as $12,034 \mathrm{~m}$ and as close as $743 \mathrm{~m}$. The bottom of the first layer is set to $1 \mathrm{~m}$ below msl to ensure dry cells are not produced if the water table drops below the cells' bottom. The remaining 20 layers vary gradually in thickness, where the upper layers are the thinnest (Fig. 2c). The horizontal grid spacing is a consistent $490 \mathrm{~m} \times 490 \mathrm{~m}$.

\section{Model calibration}

\section{Calibration approach}

Typical calibration approaches were used to estimate parameters of interest that gave the best match between measured and simulated head, salinity, nutrient concentrations, and submarine spring flux rates, with root-mean-square error (RMSE) as the criterion for assessing match quality. Available measurements were described earlier in section 'Available data'. The number of calibration parameters was minimized by utilizing independently estimated values to the extent of their availability. The calibrated parameters were horizontal hydraulic conductivity $\left(K_{\mathrm{h}}\right)$, vertical anisotropy $\left(K_{\mathrm{h}} / K_{\mathrm{v}}\right)$, porosity $(\varphi)$, and longitudinal dispersivity $\left(\alpha_{\mathrm{L}}\right)$, and their values were constrained based on available literature ranges. Parameters that were not calibrated were specific yield $\left(S_{\mathrm{y}}\right)$ and specific storage $\left(S_{\mathrm{s}}\right)$.

Two approaches were adopted for calibrating $K_{\mathrm{h}}$. In the first, a homogeneous $K_{\mathrm{h}}$ was assumed, and nine trial-anderror iterations were performed for calibration, where only one parameter varied per iteration. In addition, sensitivity analyses were completed to quantify the effect of potential model parameter variations on the modeling results (Cacuci 2003) (see section S.3 of the ESM for details). In a second approach, a heterogeneous $K_{\mathrm{h}}$ distribution was calibrated using the principal component geostatistical approach (PCGA) as a scalable inversion method for spatially distributed field characterization (Lee and Kitanidis 2014; Lee et al. 2016). Using both head levels and salinity measurements in wells for calibration, spatially distributed $K_{\mathrm{h}}$ points were 
estimated. A prior statistical correlation structure, modeled by an exponential covariance function with the scale length of $2,000,2,000$, and $200 \mathrm{~m}$ in the $x, y$, and $z$ directions, respectively, was determined by a Bayesian hyperparameter optimization approach (Kitanidis 1996) and used as a constraint for the calibration. An open-source Python package (Lee 2021) was linked to the USGS SEAWAT model and approximately 200 SEAWAT model runs were needed to obtain calibration results.

\section{Parameter ranges}

Few studies have computed $K_{\mathrm{h}}$ values for West Hawai' $i$ aquifers. Using specific capacity data, Rotzoll and El-Kadi (2008) computed $K_{\mathrm{h}}$ values that range from 155 to $11,000 \mathrm{~m} /$ day within the Keauhou aquifer, and Oki (1999) simulated Kona's groundwater system by assigning a $K_{\mathrm{h}}$ of 2,300 m/ day to the dike-free volcanic rocks. A $K_{\mathrm{h}} / K_{\mathrm{v}}$ value of 200 was calculated by Souza and Voss (1987), which is consistent with lava flow orientation and fracture configuration, and is generally accepted for Hawai'i-based groundwater models (e.g., Voss and Souza 1987; Oki 1999). Values of $\varphi$ for O'ahu's aquifers range from 0.05 to 0.5 due to the varying degrees of island weathering and age (Izuka 2011). Within that range, Oki (1999) and Izuka (2011) used a homogeneous value of 0.1 for Kona groundwater models. Estimates of $\alpha_{\mathrm{L}}$ were introduced by Oki (2005), Izuka (2011), and Glenn et al. (2013); however, the scale dependence of $\alpha_{\mathrm{L}}$ is emphasized by previous studies (e.g., Gelhar et al. 1992; Lee et al. 2018). Schulze-Makuch (2005) estimated that $\alpha_{\mathrm{L}}$ ranges from 0.1 to $100 \mathrm{~m}$ for basalts using a scale-dependent regression equation. Previous values of $S_{\mathrm{y}}$ range from 0.04 to 0.055 (Gingerich and Voss 2005; Izuka 2011) and values of $S_{\mathrm{s}}$ range from $2.3 \times$ $10^{-5}$ to $2.4 \times 10^{-5} \mathrm{~L} / \mathrm{m}$ (Oki 1999; Izuka 2011).

\section{Boundary conditions}

The regional model estimated that approximately $470,000 \mathrm{~m}^{3}$ of water enters the basal aquifer per day. That value was adjusted based on calibration to $388,399 \mathrm{~m}^{3} /$ day and assigned to the top two layers of the eastern boundary (Fig. 2c). Because urban developments also exist within the high-level aquifer, the eastern boundary was assigned specified salinity, $\mathrm{N}$, and $\mathrm{P}$ concentrations of $0.26 \mathrm{ppt}, 1 \mathrm{mg} / \mathrm{L}$, and $0.1 \mathrm{mg} / \mathrm{L}$, respectively. These concentrations were the average of the median concentrations measured from pumping wells located within $1 \mathrm{~km}$ around the boundary. These include a combination of five high-level wells and five basal wells. The ocean floor was treated as a general head (or head dependent) boundary (Fig. 2c), with a conductance of $1 \mathrm{~m}^{2} / \mathrm{day} / \mathrm{m}^{2}$ and a salinity of 35 ppt. The conductance was estimated based on coastal leakance ranges proposed by Oki (1999). All other boundaries were assigned a no-flow condition.

\section{$\delta^{15} \mathrm{~N}$ model validation}

There are numerous ways nutrients are introduced to the groundwater system in the study site, including pointsources such as OSDS and WWTP, and diffusive nonpointsources such as LULC (Kendall and Aravena 2000). Because multiple nutrient inputs are located within Keauhou and because their $\delta^{15} \mathrm{~N}$ and $\delta^{18} \mathrm{O}$ of $\mathrm{NO}_{3}{ }^{-}$composition ranges overlap, it is difficult to identify the relative contribution of each nitrogen source. Relative N contributions from OSDS, WWTP, LULC, and eastern boundary condition (BC) were estimated by assigning different $\mathrm{N}$ species to these sources. The model is equipped to simultaneously simulate these as distinct species. Following the principle of superposition, the total $\mathrm{N}$ concentration was estimated by summing these individual concentrations (Reilly et al. 1984).

To validate the modeled source estimates, $\delta^{15} \mathrm{~N}$ in dissolved $\mathrm{NO}_{3}{ }^{-}$were used to identify nitrogen sources in the aquifer; however, the analysis is complicated by the fact that each source exhibits overlapping ranges in isotopic composition. Abaya et al. (2018) measured $\delta^{15} \mathrm{~N}$ from various $\mathrm{N}$ sources in Puakō, which is located on the coast north of the study area. The study estimated natural soil $\delta^{15} \mathrm{~N}$ ranges from approximately $1-4 \%$. While most $\delta^{15} \mathrm{~N}$ samples collected within the Keauhou basal aquifer fall within the natural soil $\delta^{15} \mathrm{~N}$ range (e.g., Kendall and Aravena 2000), elevated $\mathrm{NO}_{3}{ }^{-}$measurements for some samples suggest $\mathrm{N}$ is added by other inputs as well. To test this, a simple isotope mixing equation was used to compute $\delta^{15} \mathrm{~N}$ values for wells and submarine springs based on simulated relative contributions and $\delta^{15} \mathrm{~N}$ endmember assumptions.

Since mixing ratios are used for stable isotopes of dissolved components, $\delta^{15} \mathrm{~N}$ needs to be weighted by the simulated concentrations in the mixing model (Hunt and Rosa 2009). The following mixing equation was used (Hunt and Rosa 2009):

$\delta^{15} \mathrm{~N}_{\text {model }}=\frac{\left(f_{\text {OSDS }} C_{\text {OSDS }} d \mathrm{~N}_{\text {OSDS }}\right)+\left(f_{\text {LULC }} C_{\text {LULC }} d \mathrm{~N}_{\text {LULC }}\right)+\left(f_{\mathrm{WWTP}} C_{\mathrm{WWTP}} d \mathrm{~N}_{\mathrm{WWTP}}\right)+\left(f_{\mathrm{BC}} C_{\mathrm{BC}} d \mathrm{~N}_{\mathrm{BC}}\right)}{\left(f_{\mathrm{OSDS}} C_{\mathrm{OSDS}}\right)+\left(f_{\mathrm{LULC}} C_{\mathrm{LULC}}\right)+\left(f_{\mathrm{WWTP}} C_{\mathrm{WWTP}}\right)+\left(f_{\mathrm{BC}} C_{\mathrm{BC}}\right)}$

where $\delta^{15} \mathrm{~N}_{\text {model }}$ is the computed $\delta^{15} \mathrm{~N}$ at wells and submarine springs, $f$ is the simulated fraction of each source component at a well or submarine spring location, $C$ is the simulated concentration in the component, and $d \mathrm{~N}$ is the $\delta^{15} \mathrm{~N}$ 
endmember of each source component. The $\delta^{15} \mathrm{~N}$ endmembers used for OSDS, WWTP, LULC, and BC were 7\%o (Wiegner et al. 2016), 1\%o (Abaya et al. 2018), 20\%o (Hunt 2014), and 2\%o (Hunt 2014), respectively. Single endmember values were selected to obtain the best match, but as previously mentioned, each source ranges in $\delta^{15} \mathrm{~N}$. Wiegner et al. (2016) summarized that $\delta^{15} \mathrm{~N}$ for sewage in Hawai'i ranges from 7 to $20 \%$, while Abaya et al. (2018) narrowed the range to $9-11 \%$ in Puakō, Hawai'i Island. Abaya et al. (2018) reported that values for fertilizers range from -2 to $0 \%$ while soil ranged from 1 to $4 \%$. Since the modeled LULC coverage contains natural land and urbanized land, both ranges were considered. Hunt (2014) reported that the treated wastewater from Kealakehe had a $\delta^{15} \mathrm{~N}$ measurement of $12 \%$ and a water sample from a well within the Kealakehe wastewater plume had a $\delta^{15} \mathrm{~N}$ measurement of 20\%o. Hunt (2014) reported that the Honokōhau well, which is a high-level pumping well in Keauhou, had a $\delta^{15} \mathrm{~N}$ measurement of $2 \%$. This is similar to this study's high-level samples, which ranged from 1 to $2 \%$.

\section{Freshwater-only model}

As previously stated, models overlooking salinity changes in nearshore aquifers are commonly used to assess both water levels and quality. To test applicability of such an approach, a freshwater-only model was simulated to compare to the density-dependent results. The model was easily set by converting SEAWAT to run MODFLOW and MT3DMS in sequence, with MODFLOW set to run in a steady-state condition. The model retained the boundary conditions, coverages, and various input parameters previously described, except $K_{\mathrm{h}}$, which was recalibrated to obtain a reasonable match for hydraulic head under freshwater-only settings.

\section{Model applications}

To demonstrate the capability of the density-dependent model as a management tool addressing nutrient and salinity distribution in the basal aquifer, the model was tested with example applications. This study therefore focused on two different aspects that are important for water resource management in West Hawai'i: (1) aquifer salinity and storage changes as a response to future development and climate change, and (2) aquifer response to sea level rise.

\section{Aquifer response to urban development and climate change}

Accounting for future water demand is crucial in ensuring that the aquifer will not be over-pumped or subjected to water quality deterioration with anticipated urban expansion. As an example use of the model, a future urban development application was created by altering the LULC map described in section 'Current land use and land cover (LULC)' (Fig. 2f). The Kona Water Use Development Plan identified areas where new development is expected to occur based on allocated water permits (Fukunaga 2017). These new development areas were designated anticipated water demands, where a demand of $1.5 \mathrm{~m}^{3} /$ day corresponds to one residential unit (Fukunaga 2017). The water demand, however, does not necessarily correlate with a particular development intensity level. In the majority of cases, new development occurred in areas characterized as natural background, where there is no current development. These areas were therefore assigned nutrient concentrations associated with medium intensity development, the most common development intensity in the area. In some areas, however, new development involved adding units to previously developed land. In this case, anticipated water demands for the new parcels (Fukunaga 2017) were used to determine whether the development intensity would significantly change with the additional development. Since one residential unit does not appear to be a significant addition to an already medium- or high-density area, development intensity was assumed to remain the same where anticipated water demand was $1.5 \mathrm{~m}^{3} /$ day (adding one or less new home) but was assumed to increase from medium intensity to high intensity where anticipated water demand was $>1.5 \mathrm{~m}^{3} /$ day (adding more than one new home).

Based on current legal regulations in Hawai' $i$ (Act 125), all cesspools are required to be replaced by 2050 , so future development will need to be connected to sewer lines or replaced with septic or aerobic treatment (ATU) systems. For simplification purposes, it was assumed that the first option would be adopted. It is also assumed that $50 \%$ of the total water demand from new development will be used outdoors (Board of Water Supply 2021), so the remaining $50 \%$ will be routed to the Kealakehe WWTP via sewer lines. With a total future water demand of approximately $64,080 \mathrm{~m}^{3} /$ day across Keauhou (Fukunaga 2017), 32,040 $\mathrm{m}^{3} /$ day will be directed to the Kealakehe WWTP, which results in 724 and $225 \mathrm{~kg}$ /day of additional $\mathrm{N}$ and $\mathrm{P}$ mass load, respectively. Combining this with the already existing mass load, the disposal percolation basin was simulated to receive total $\mathrm{N}$ and $\mathrm{P}$ mass loads of 868 and $270 \mathrm{~kg} /$ day, respectively. Concurrently, the total future water demand is assumed to be pumped from the high-level wells in the Keauhou aquifer, so $64,080 \mathrm{~m}^{3} /$ day was removed from the eastern boundary condition, thus reducing the influx to $324,319 \mathrm{~m}^{3} /$ day.

Further, Elison-Timm et al. (2015) estimated the change in rainfall for the state of Hawai' $i$ using statistical downscaling methods with the Coupled Model Intercomparison Project phase 5 (CMIP5) Representative Concentration Pathway (RCP) 4.5 and 8.5 results. Based on these projections, Hawai'i Island may experience an approximately 16-40\% average reduction in rainfall by 2100 (Elison-Timm et al. 2015). Based on interpolated maps, the Keauhou area may 
experience approximately $20 \%$ reduction in rainfall following the RCP 8.5 scenario (Elison-Timm et al. 2015). It is outside the scope of this project to create a new recharge coverage by computing a water budget under climate change conditions; therefore, to account for the overall reduction in rainfall expected at the end of the century, the current recharge computed by the USGS (Engott 2011) was simply reduced by $20 \%$ across the entire basal aquifer.

\section{Aquifer response to sea level rise}

As a coastal aquifer, impacts of future sea level rise are of great concern. Global sea level is predicted to rise approximately $1 \mathrm{~m}$ by the end of the century, if greenhouse gas emissions continue to rise at the current rate (e.g., Pfeffer et al. 2008; Nichols and Cazenave 2010; Hawai' $i$ Climate Change Mitigation and Adaptation Commission 2017). To simulate future sea level rise, the offshore head stage was set to $1 \mathrm{~m}$ above msl to assess how increasing levels could potentially impact submarine spring flux rate and salinity.

\section{Results and discussion}

\section{Density-dependent model calibration}

Utilizing a heterogeneous $K_{\mathrm{h}}$ distribution, as described in section 'Calibration approach', did not lead to a significant improvement in results (section S.4 in the ESM). Accuracy of salinity calibration in wells improved but was accompanied with a slightly reduced accuracy of hydraulic head calibration; additionally, the accuracy of $\mathrm{N}$ and $\mathrm{P}$ predictions worsened. It was concluded that such an effort is only useful if appropriate representation of various processes is included in the conceptual model. Under scarcity of data, utilizing a simplified $K_{\mathrm{h}}$

Table 2 Calibrated parameter values used in the Keauhou basal aquifer model

\begin{tabular}{lll}
\hline Parameter & Unit & Value \\
\hline Hydraulic conductivity $\left(K_{\mathrm{h}}\right)$ & $\mathrm{m} /$ day & 2,500 \\
Vertical anisotropy $\left(K_{\mathrm{h}} / K_{\mathrm{v}}\right)$ & dimensionless & $200^{\mathrm{a}, \mathrm{b}}$ \\
Porosity $(\varphi)$ & dimensionless & $0.1^{\mathrm{b}, \mathrm{c}}$ \\
Specific yield $\left(S_{\mathrm{y}}\right)$ & dimensionless & $0.06^{\mathrm{c}, \mathrm{d}}$ \\
Specific storage $\left(S_{\mathrm{s}}\right)$ & $\mathrm{L} / \mathrm{m}$ & $2.6 \times 10^{-5} \mathrm{~b}, \mathrm{c}$ \\
Longitudinal dispersivity $\left(\alpha_{\mathrm{L}}\right)$ & $\mathrm{m}$ & 50 \\
Eastern boundary flux & $\mathrm{m}^{3} /$ day & 388,399 \\
\hline
\end{tabular}

${ }^{\text {a }}$ Voss and Souza (1987)

${ }^{\mathrm{b}}$ Oki (1999)

${ }^{\mathrm{c}}$ Izuka (2011)

${ }^{\mathrm{d}}$ Hunt (1996) distribution is preferred, considering the complications and computational expenses associated with developing a more involved $K_{\mathrm{h}}$ distribution. The results presented from here forward are all for a homogeneous $K_{\mathrm{h}}$ applied to the entire aquifer. The final calibrated parameter values used in the Keauhou basal aquifer model are provided in Table 2.

Head, salinity, $\mathrm{N}$ and $\mathrm{P}$ concentration calibration results are shown in Fig. 3. Head was reasonably calibrated with a relatively low RMSE ( $<0.5 \mathrm{~m}$; Fig. 3a). Under density-dependent conditions, the calibration process is complicated by the nonlinear relationship between the hydraulic head and salinity. Attempts to improve on the accuracy of salinity calibrations resulted in less precise head calibrations. The reasonable accuracy of head prediction, nonetheless, implies validity of the continuum approach via Darcy's law (e.g., Bear 1972) for simulating the hydraulic head for this complex domain. However, lower accuracy and the scatter regarding salinity and nutrients are likely attributed to the complexities in geological characteristics of the field such as the potential existence of preferential flow, which would naturally affect various simulation processes. The simulated salinity in submarine springs exhibit lower accuracy due to the nature of sampling location. Submarine springs are simulated along the shoreline and are positioned at the interface between fresh groundwater exiting the aquifer and saline ocean water moving inland. Thus, most of the submarine springs have a simulated salinity confined within a narrow range in comparison to the wide range of salinities measured in the field (Fig. 3b). This mismatch is possibly caused by the model's inability to simulate a very precise spring point location. The field-based submarine spring salinity measurements were assessed from the freshest terrestrial water that could be detected at the coast; thus, they are expected to be biased towards lower values. In contrast, the modeled salinity was averaged over an entire cell, and therefore falls within a mid-salinity range.

The $\mathrm{N}$ simulations produce reasonable calibration results (Fig. 3c,d). In contrast, many of the observed P measurements fall within a small range that is not well represented in the model results (Fig. 3e,f). The imprecise results for $\mathrm{P}$ should be expected considering that the assumption of a conservative behavior is not valid (Delevaux et al. 2018); however, the results can be useful while applying the model for screening purposes. In contrast to salinity, the relatively better correlation between simulated and measured $\mathrm{N}$ and $\mathrm{P}$ for submarine springs is due to the fact that these species are primarily sourced from terrestrial sources located in freshwater zones and not drastically influenced by marine processes at the land-ocean interface.

Modeling submarine springs as drain points with varying conductance produced accurate results (RMSE $=1,237 \mathrm{~m}^{3}$ / day, $\left.r^{2}=0.98\right)$. Under such conditions, the model simulated $107,673 \mathrm{~m}^{3} /$ day of groundwater discharging at point-source submarine springs, closely matching the observed values. The 

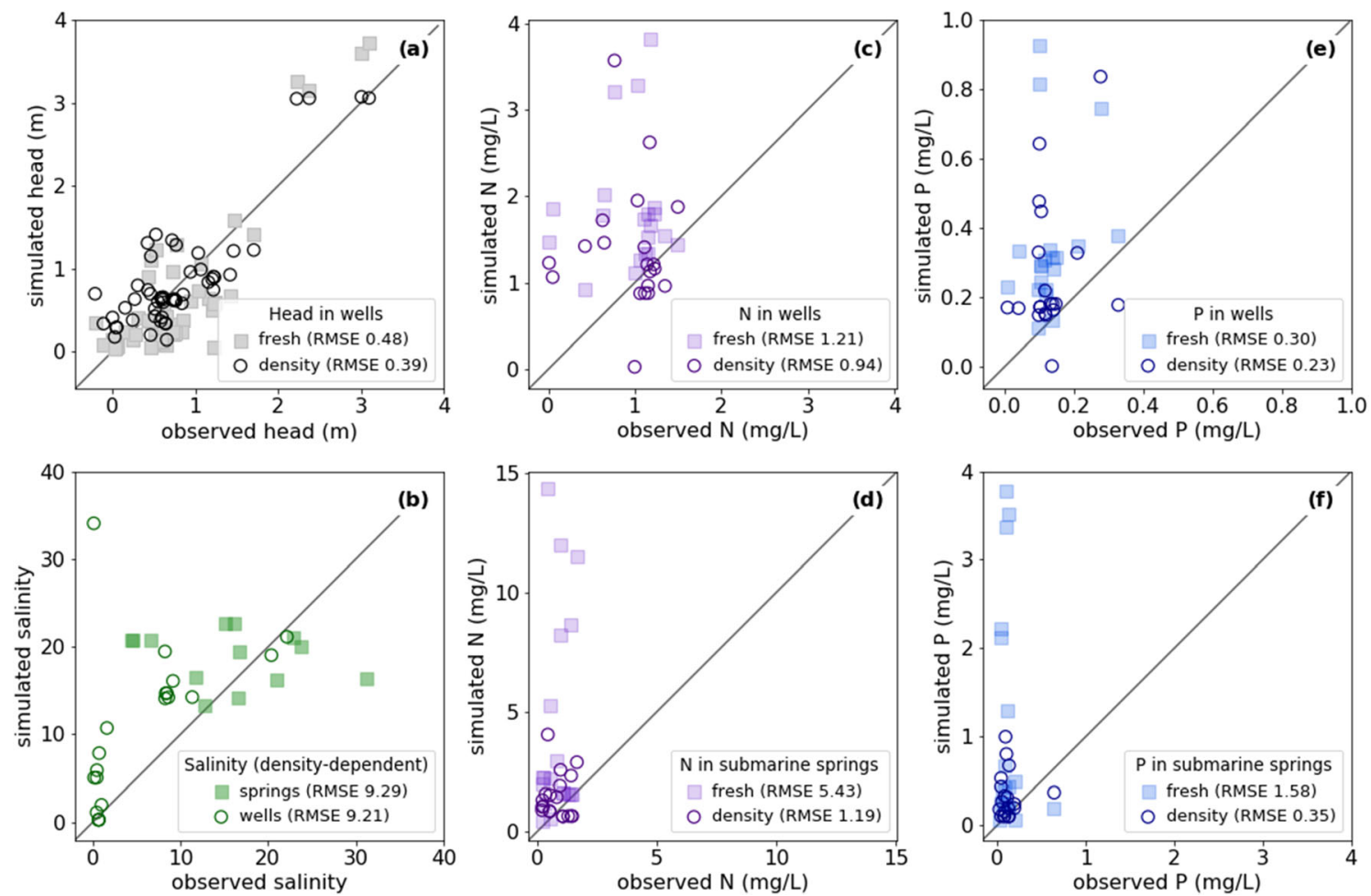

Fig. 3 Scatter plots of density-dependent and freshwater-only model calibration results for a head, $\mathbf{b}$ salinity, $\mathbf{c} \mathrm{N}$ in wells, $\mathbf{d ~ N}$ in submarine springs, e $\mathrm{P}$ in wells, $\mathbf{f} \mathrm{P}$ in submarine springs. As it is not possible to

simulate salinity using a freshwater-only model setup, part b only contains density-dependent results. Root-mean-square errors (RMSE) are included and carry the same units as the respective measurements

model also simulated an additional 1,230,000 $\mathrm{m}^{3} /$ day of fresh and saline water diffusively discharging along the coast and offshore. However, accurately simulated flux rates combined with lower accuracy of salinity, $\mathrm{N}$, and $\mathrm{P}$ concentrations emphasize the fact that a continuum approach for flow modeling can be acceptable for preferential flow but fails to simulate solute transport.

\section{Validity of the freshwater-only model}

Although comparable head accuracy was obtained for the freshwater-only model and the density-dependent model (Fig. 3a), a significantly lower $K_{\mathrm{h}}$ of $300 \mathrm{~m} /$ day was required to calibrate the hydraulic head. Compared to a value of $2,500 \mathrm{~m} /$ day for the density-dependent model, such a value is not realistic for a young basalt, as documented in previous modeling and other studies (Oki 1999; Izuka 2011). Hence, such a value can simply be considered as a fitting parameter that is not physically based. It is of interest to note that $K_{\mathrm{h}}$ appears to be a process-based parameter, thus it depends on the nature of the conceptual model and processes simulated. Saltwater circulation clearly affects the estimated effective aquifer thickness, which cannot be accurately estimated by a freshwater-only model. RMSE of submarine spring flux also increased from $1,237 \mathrm{~m} /$ day to $3,273 \mathrm{~m} /$ day. Although the submarine spring drains retained the same conductance values, the lower $K_{\mathrm{h}}$ assigned to the freshwater-only model reduced overall flow fields (Fig. 4b) and resulted in lower discharge at the submarine springs.

The overall accuracy of $\mathrm{N}$ and $\mathrm{P}$ concentrations are comparable for the two models at wells (Fig. 3c,e), in contrast to the values in the submarine springs (Fig. $3 \mathrm{~d}$,f). The freshwater-only model overestimates nutrient concentrations in the springs due to the fact that water circulation is not simulated in the nearshore area, where in reality, nutrientpoor saltwater intrudes into the aquifer. As should be expected, the influence of circulation diminishes far from the shoreline, leading to better accuracy for wells. Flow fields for the two models are compared in Fig. 4, showing a significant contrast in the nearshore area. It should be noted that salinity does not directly affect nutrient concentrations, considering that they are treated as conservative species. The case can be different for reactive chemicals such as contaminants of emerging concern (CECs), where salinity can directly play a role (e.g., Patel et al. 2019; McKenzie et al. 2020). It can be concluded that, not only does the freshwater-only model overlook salinity, but it also ignores the significant water circulation in the nearshore environment, leading to unacceptable errors in water quality assessment. Salinity is an important factor regarding water sustainability concerning different water uses, such as reducing estimates of aquifer sustainable yield and causing damage to anchialine ponds. Fresh groundwater in Hawai' $i$ is considered to have less than $1,000 \mathrm{mg} / \mathrm{L}$ of dissolved solids (Yee 1987), while the USGS also classifies 

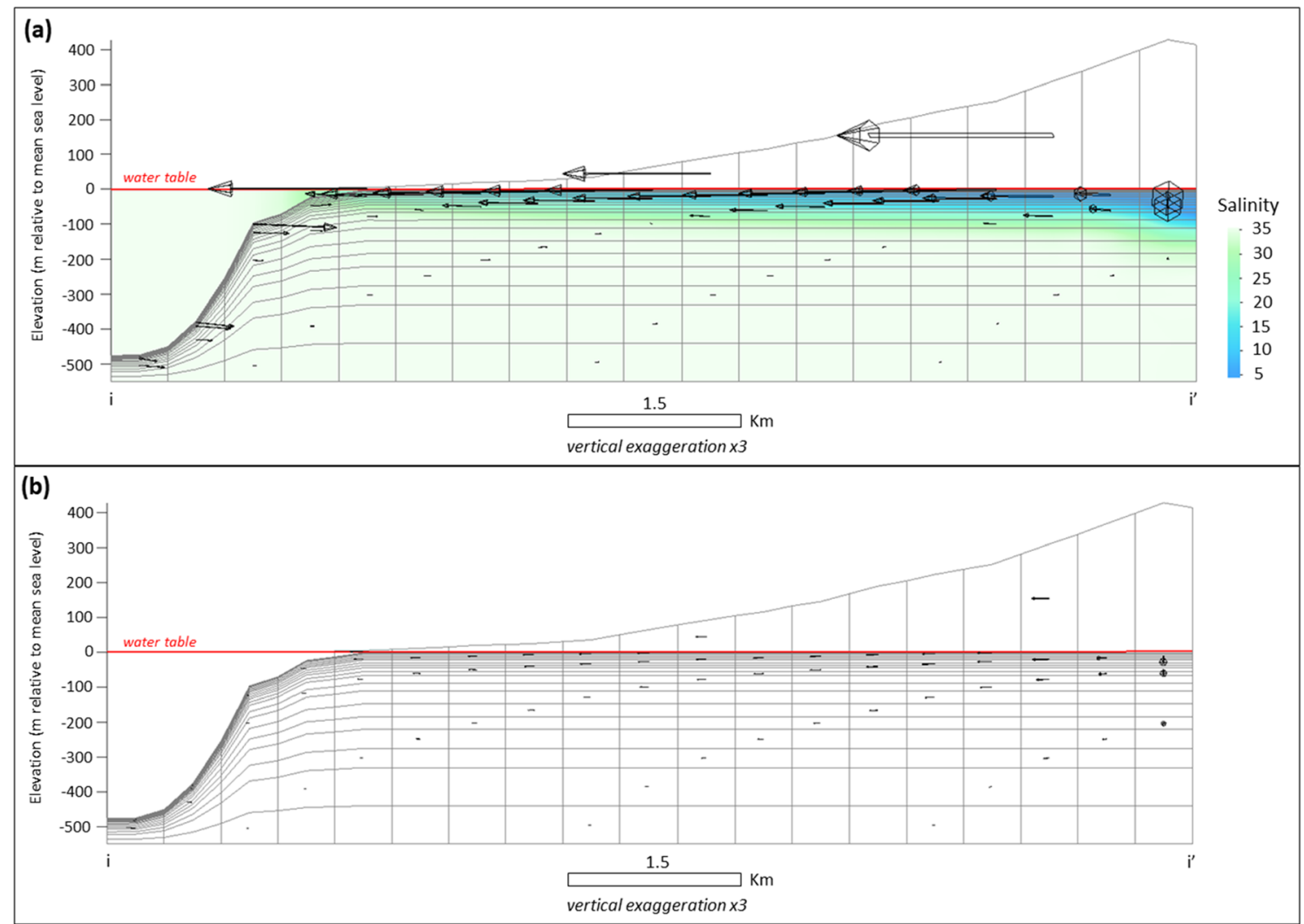

Fig. 4 Vertical cross section $\mathrm{i}-\mathrm{i}^{\prime}$ (Fig. 2a) of flow vectors for the a density-dependent model and $\mathbf{b}$ freshwater-only model. The vector lengths vary according to magnitude. The density-dependent model also contains salinity contours, displaying a relatively thin freshwater lens.

water as "slightly saline" with concentration less than $3,000 \mathrm{mg} / \mathrm{L}$ (Swenson and Baldwin 1965). If it is assumed that salinity measurements directly correspond to dissolved solid concentrations, then $45 \%$ of the 20 wells used in the Keauhou basal aquifer model had salinity measurements that exceed the "slightly saline" water standard, while $75 \%$ of the simulated salinity measurements exceed the threshold. Such an assessment clearly indicates the need for a densitydependent model to accurately assess water sustainability and estimate aquifer sustainable yield.

\section{Relative $\mathrm{N}$ source contributions and $\delta^{15} \mathrm{~N} \mathrm{NO}_{3}{ }^{-}$ model validation}

Based on simulated $\mathrm{N}$ mass loadings entering the Keauhou basal aquifer, the majority of $\mathrm{N}$ is sourced from OSDS (54\%), while urban development LULC contributed 10\%, the Kealakehe WWTP contributed 9\%, and groundwater applied at the eastern boundary contributed $26 \%$ (Fig. 5). It is clear that OSDS have the greatest impact on nutrient contribution to the groundwater system. Areas with urban development, where there are significant clusters of OSDS, experience plumes of higher nutrient concentrations, which travel with groundwater flow to the coast (Fig. 5b). The results can be
Flow vectors within the lens are directed towards the coast, while flow vectors within the underlying saltwater body are directed inland. As should be expected, freshwater-only vectors move towards the ocean

useful for managing water quality issues such as efforts to meet Federal regulations regarding the total maximum daily load and identifying major contributor sources where upgrade efforts should be directed. For this study, it is important to recognize the significant nutrient mass load that is sourced from the eastern boundary condition (Fig. 5e), especially while considering the boundary uncertainties previously discussed. The mass load that enters through the boundary was dependent on the assigned nutrient concentrations and water flux.

Based on simulated $\mathrm{N}$ concentrations in wells and submarine springs, relative $\mathrm{N}$ source contributions were also estimated at each sample location (Fig. 6). Overall, minimal amounts of LULC-sourced $\mathrm{N}$ were detected in simulated samples, with an average contribution of $0.13 \mathrm{mg} / \mathrm{L}$ (13\% of total concentration). The N sourced from the WWTP contributed a significant amount of $\mathrm{N}$ to a few submarine springs. An estimated $57-71 \%$ of WWTP-sourced N was simulated in the two submarine springs (HHA and HHB) located directly downgradient of the WWTP. This was also validated by the enriched $\delta^{15} \mathrm{~N}$ measured at these submarine springs (Fig. 6). Simulated N sourced from OSDS and the eastern boundary were both significantly detected in most wells and submarine springs. Of importance is to note that OSDS-sourced $\mathrm{N}$ 

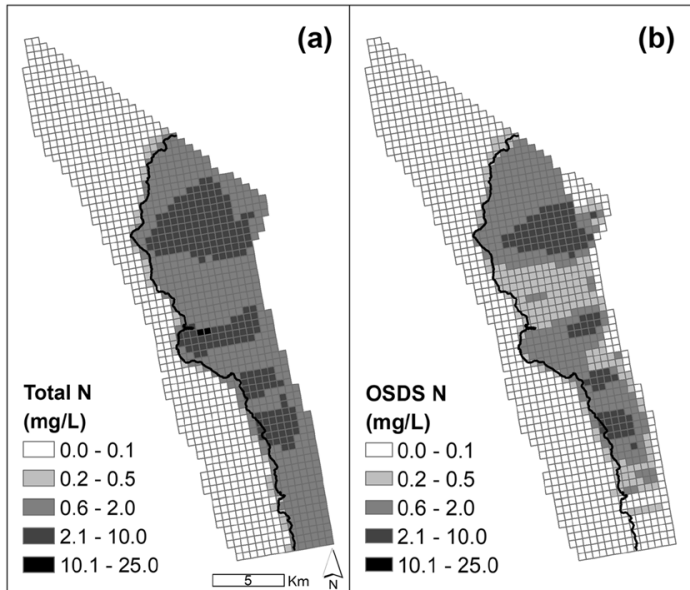

(b)

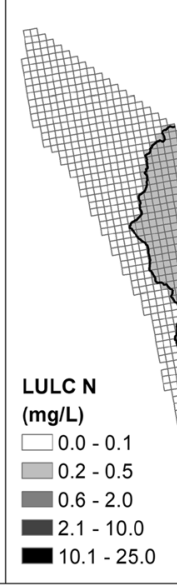

Fig. 5 Simulated a total groundwater $\mathrm{N}$ concentration and relative contributions of $\mathbf{b}$ on-site sewage disposal systems (OSDS), $\mathbf{c}$ land use and land cover (LULC), d Kealakehe Wastewater Treatment Plant

appears in all but one sample across the aquifer, demonstrating the widespread effect of wastewater on groundwater quality. Eight of the 25 simulated samples had at least $50 \%$ of the simulated $\mathrm{N}$ concentration sourced from OSDS, while 11 samples had at least $50 \%$ of $\mathrm{N}$ sourced from the eastern boundary (Fig. 6). Conversely, the average OSDS-sourced $\mathrm{N}$ concentration was $0.6 \mathrm{mg} / \mathrm{L}$, while the average boundarysourced $\mathrm{N}$ concentration was $0.4 \mathrm{mg} / \mathrm{L}$.

Calculated $\delta^{15} \mathrm{~N}$ values were used to validate simulated $\mathrm{N}$ contributions. Results from the described isotope mixing model (section ' $\delta{ }^{15} \mathrm{~N}$ model validation') produced a reasonable fit (c)

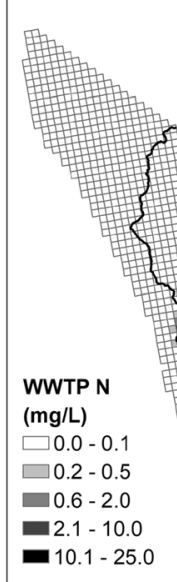

(d)

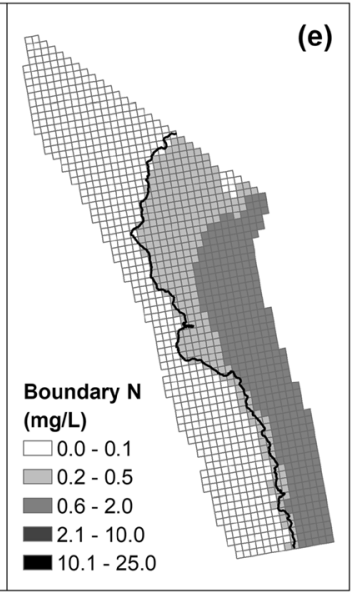

(WWTP), e eastern boundary N sources in the Keauhou basal aquifer. Mapped grids display the $\mathrm{N}$ concentrations of each source simulated in the second layer of the model

between the measured and computed $\delta^{15} \mathrm{~N}$ values $\left(r^{2}=0.76\right)$, where 14 of the 25 samples matched within $\pm 1 \%$ o (Fig. 7). Considering that $\delta^{15} \mathrm{~N}$ values vary over a range within each source, the mixing results are influenced by uncertainties associated with endmember designations. Since relative N contributions from LULC and WWTP were minimal, variations in $\delta^{15} \mathrm{~N}_{\text {LULC }}$ and $\delta^{15} \mathrm{~N}_{\text {WWTP }}$ endmembers did not drastically affect overall $\delta^{15} \mathrm{~N}_{\text {model }}$ results (Fig. 7a,b). Although the $\mathrm{N}$ contribution from the $\mathrm{BC}$ was relatively high, the $\delta^{15} \mathrm{~N}_{\mathrm{BC}}$ range was not large enough to significantly affect $\delta^{15} \mathrm{~N}_{\text {model }}$ results (Fig. 7c). Since the $\mathrm{BC}$ is an ambiguous endmember with mixed water sources,

Fig. 6 Simulated N contributions (bar plots) from on-site sewage disposal systems (OSDS), land use and land cover (LULC), the wastewater treatment plant (WWTP) and eastern boundary condition (BC) at each well and submarine spring location where a $\delta^{15} \mathrm{~N}$ sample was measured. Corresponding $\delta^{15} \mathrm{~N}$ measurements are represented by circle markers. Small grey squares represent OSDS locations and the red square represents the WWTP location

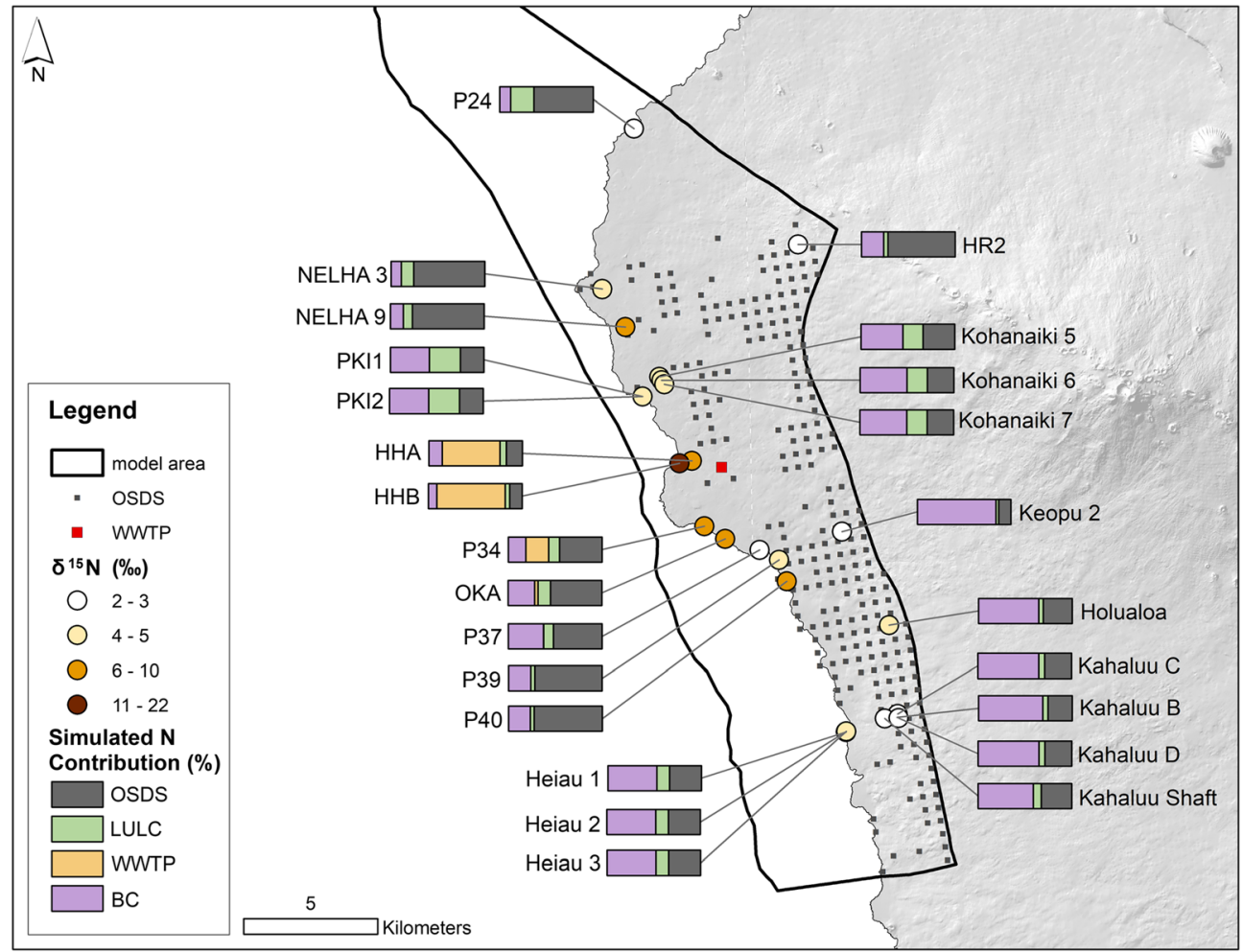


Fig. 7 Mixing model results for measured and computed

$\delta^{15} \mathrm{~N}_{\text {nitrate }}$ using simulated relative $\mathrm{N}$ source contributions. Grey squares represent $\delta^{15} \mathrm{~N}$ mixing model results with selected endmembers. Black error bars show result uncertainty based on $\delta^{15} \mathrm{~N}$ ranges for a land use and land cover (LULC), b wastewater treatment plant (WWTP), c eastern boundary condition (BC), and $\mathbf{d}$ on-site sewage disposal systems (OSDS)
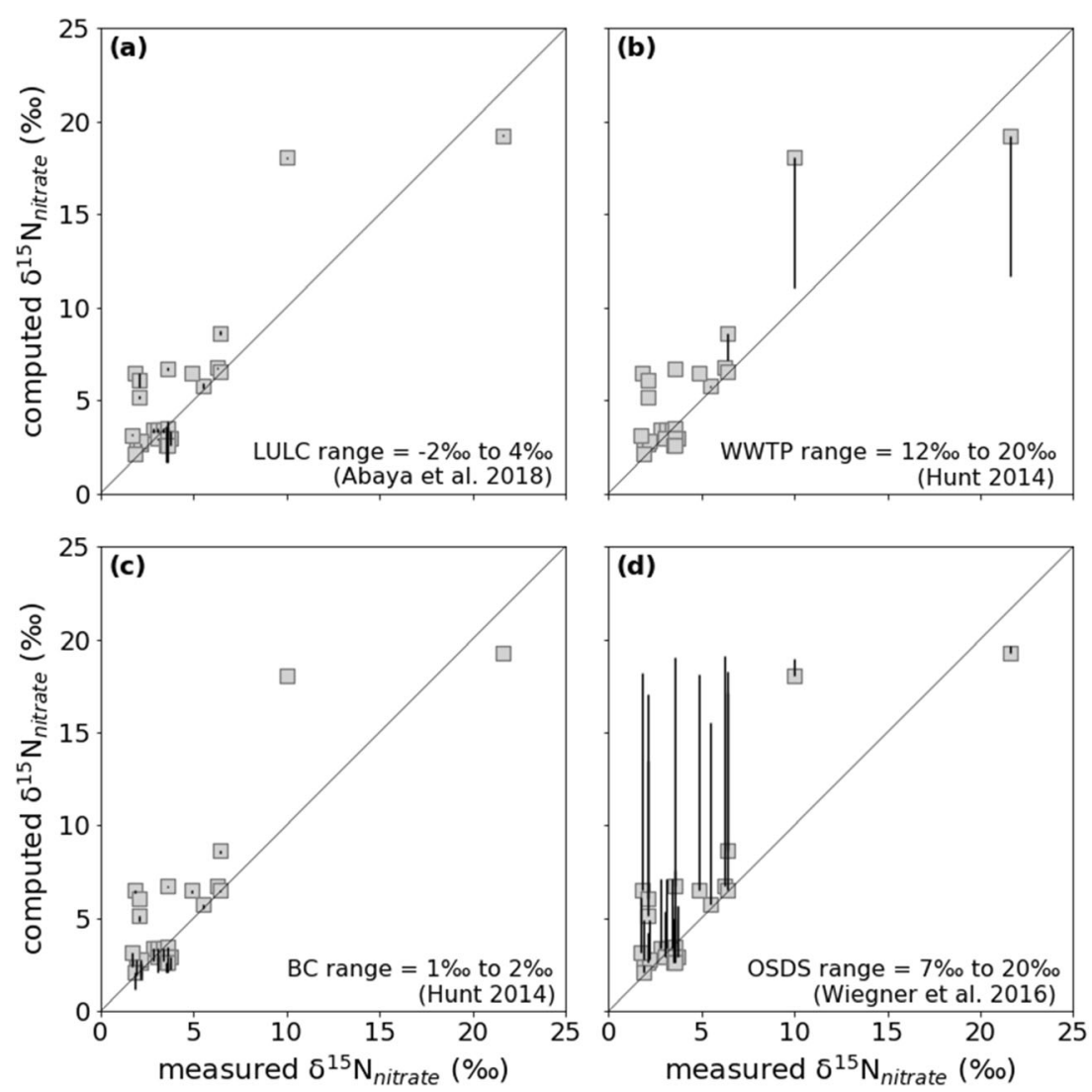

the most reliable $\delta^{15} \mathrm{~N}$ reference were water samples from highlevel pumping wells, which showed very little variation. Modeling results show that OSDS serves as the most significant $\mathrm{N}$ source, thus changes in the $\delta^{15} \mathrm{~N}_{\text {OSDS }}$ endmember exhibited the greatest variation (Fig. $7 \mathrm{~d}$ ). An enriched $\delta^{15} \mathrm{~N}_{\text {OSDS }}$ endmember would potentially enrich $\delta^{15} \mathrm{~N}_{\text {model }}$ results and thus skew relative contributions. There is a large range of OSDS $\delta^{15} \mathrm{~N}$ measurements because of the different individual units, but this approach is limited to assigning one OSDS endmember. Therefore, differences between measured and modeled $\delta^{15} \mathrm{~N}$ is to be expected; nonetheless, a reasonable fit was obtained with a $\delta^{15} \mathrm{~N}_{\text {OSDS }}$ value of $7 \%$. Although this endmember is slightly depleted compared to previously published values from other areas in Hawai'i (e.g., Wiegner et al. 2016), findings from previous studies (e.g., Abaya et al. 2018) already demonstrate that $\delta^{15} \mathrm{~N}$ measurements in West Hawai' $i$ are isotopically depleted compared to universal ranges typically found in literature (e.g., Kendall and Aravena 2000). These results therefore emphasize the importance of site-specific measurements, suggesting that more sampling from varying conditions is required and an approach acknowledging wider ranges should be considered. With these limitations in mind, the model captured overall $\delta^{15} \mathrm{~N}$ ranges. These results validate the simulated $\mathrm{N}$ transport results and show that mixing between $\mathrm{N}$ from various sources can be constrained; hence, the model can be used as a tool to estimate relative contributions of multiple nitrogen sources.

\section{Model applications}

\section{Future development and climate change}

Future urban development and climate change negatively impacted simulated head, salinity, $\mathrm{N}$ and $\mathrm{P}$ concentrations to various degrees. When only future development was considered, head was not affected (Fig. 8a) and salinity was minimally affected (Fig. 8b), due to the fact that water fluxes and input salinities were not altered. Under these development conditions, $\mathrm{N}$ and $\mathrm{P}$ concentrations primarily increased around the WWTP because the WWTP mass load increased to account for the additional wastewater generated with the additional development (Fig. 8c,d). When additional water demand was considered along with the future development, head levels expectedly declined, while salinity, $\mathrm{N}$ and $\mathrm{P}$ concentrations increased throughout the model due to the reduced water flux applied at the eastern boundary. Further, when climate change impacts were considered along with future development and additional water demand, head, salinity, $\mathrm{N}$ and $\mathrm{P}$ changes were exacerbated due to the additional water flux reduction. With less freshwater entering the simulated aquifer system, hydraulic head levels declined, with a maximum change of $-0.3 \mathrm{~m}$ (Fig. 8a). Submarine spring flow also decreased, leading to more saltwater intrusion, thus increasing salinity with a maximum change of 2 ppt. The increased 

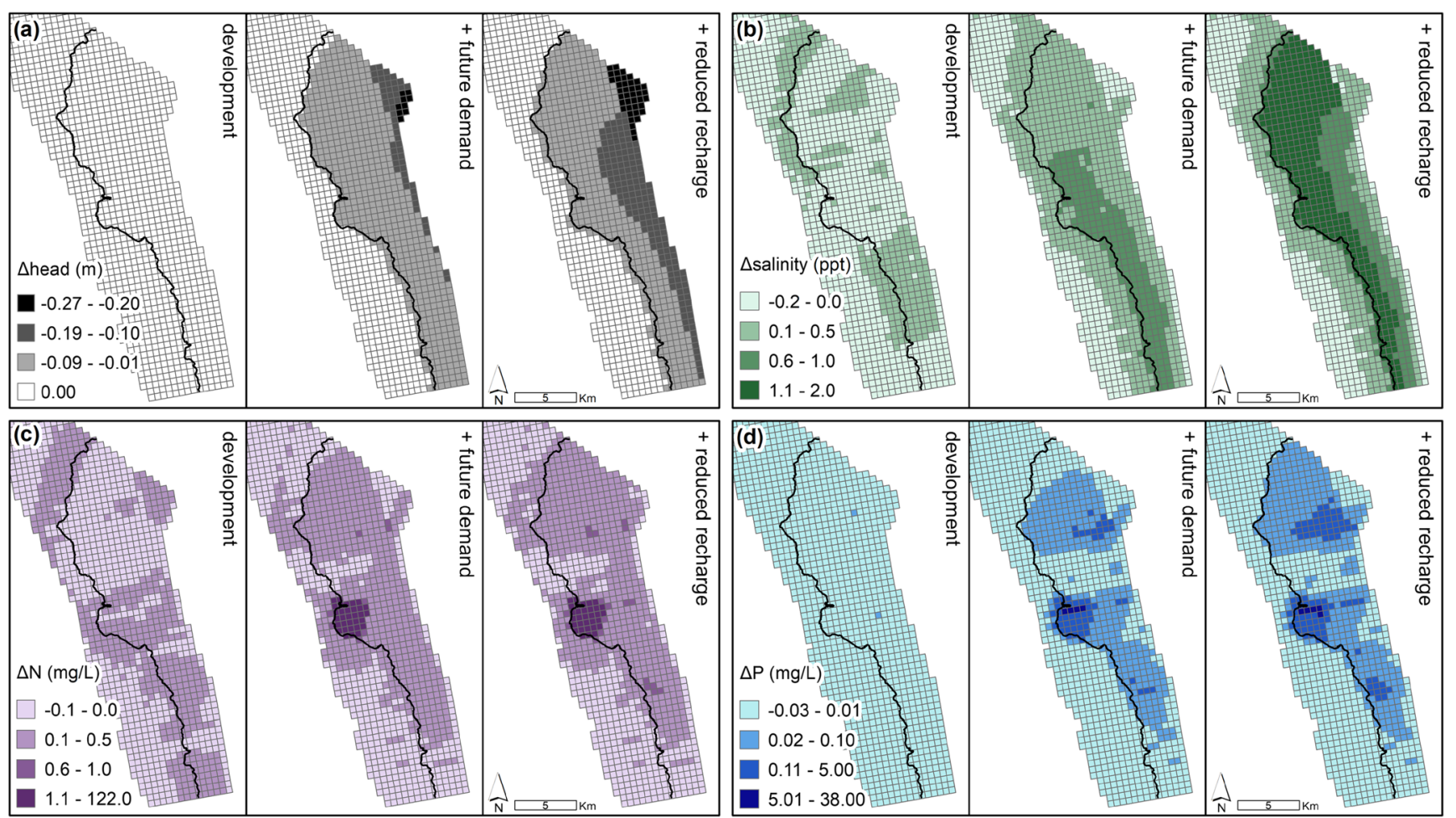

Fig. 8 Change in a head, $\mathbf{b}$ salinity, $\mathbf{c} \mathbf{N}$, and $\mathbf{d} \mathrm{P}$ concentrations from baseline conditions to future development, future development + future water demand, and future development + future water demand + reduced

recharge from climate change impacts. In all cases, changes were computed by subtracting baseline results from application results. Mapped grids display the changes in the second layer of the model

salinities are highest along the southern coast of the aquifer, which is likely due to the narrower aquifer model width (Fig. $8 b)$. Under these future conditions, the increase in $\mathrm{N}$ concentrations generally remained under $1 \mathrm{mg} / \mathrm{L}$, but increased notably up to $122 \mathrm{mg} / \mathrm{L}$ directly around the WWTP. It appears that reducing the water flux, whether due to increased water demand or climate change impacts, has the greatest impact on simulated results, while nutrient inputs from development green space does not appear to significantly alter simulated nutrient concentrations in the groundwater (Fig. 8c,d). The drastic reduction of water flux ultimately altered nutrient concentrations to a greater degree compared to the addition from urban development.

\section{Modeling sea level rise}

With $1 \mathrm{~m}$ of simulated sea level rise, the hydraulic head nearly increased by $1 \mathrm{~m}$ across the entire area of the modeled aquifer. The unaltered flux at the eastern boundary did not create a significant head gradient with the sea level rise to counter the increase in saltwater head gradient. This also resulted in approximately $1 \mathrm{~m}$ of rise of the freshwater-saltwater interface, thus ultimately lifting the entire freshwater lens. The change in salinity, however, did not occur in a simplified trend throughout the aquifer. The maximum change in salinity was $2.75 \mathrm{ppt}$, but most

cells typically demonstrated less than 1 ppt change (Fig. 9). Very little change was observed in the relatively fresher upper layers (Fig. 9a), while the greatest change was observed in the middle of the freshwater lens (Fig. 9c). Additionally, under sea level rise conditions, there was an observed increase in simulated coastal discharge. Diffuse (ocean bottom) coastal discharge decreased by approximately $120,000 \mathrm{~m}^{3} /$ day, but submarine spring discharge (via drains) increased by approximately $130,000 \mathrm{~m}^{3} /$ day. Total discharge, therefore, increased by approximately $10,000 \mathrm{~m}^{3}$ /day with $1 \mathrm{~m}$ of simulated sea level rise.

The results of this analysis are supported by Lee et al. (2013), who concluded that when longer time scales are considered, sea level rise could potentially result in an increase in submarine spring flow under certain conditions (Lee et al. 2013). Werner and Simmons (2009) suggest that sitespecific boundary conditions have a significant impact on simulation results when modeling sea level rise in coastal aquifers, and thus argue that groundwater discharge and saltwater intrusion under sea level rise conditions are sensitive to the assigned inland boundary conditions. Werner and Simmons (2009) conclude that with sea level rise, fluxcontrolled systems experience less saltwater intrusion and persistent groundwater discharge in comparison to headcontrolled systems. Results from this study support the concepts proposed by Lee et al. (2013) and Werner and Simmons 

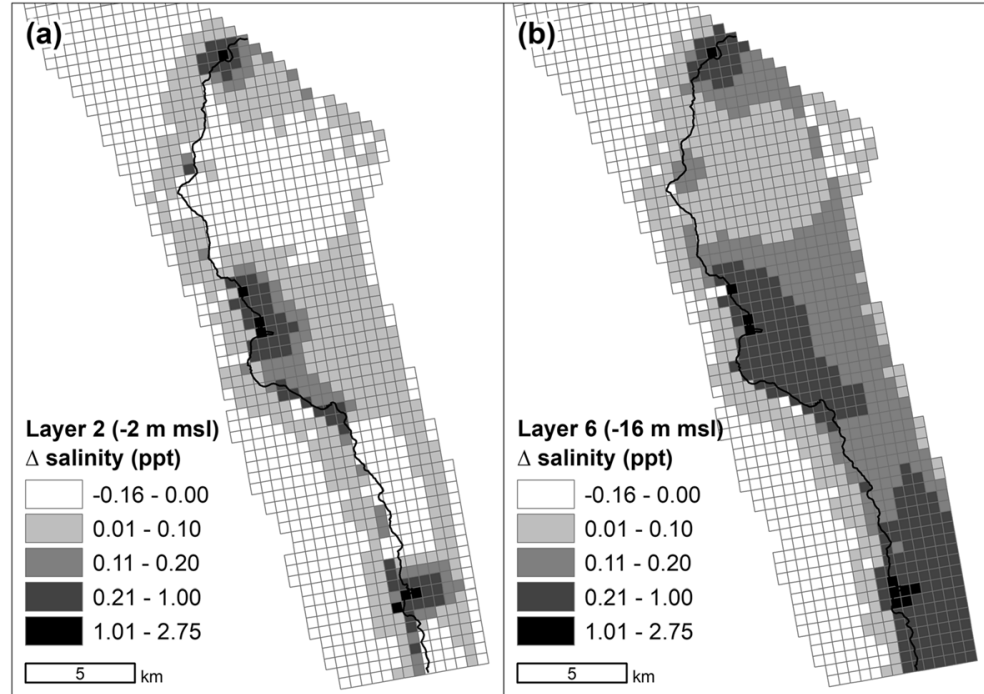

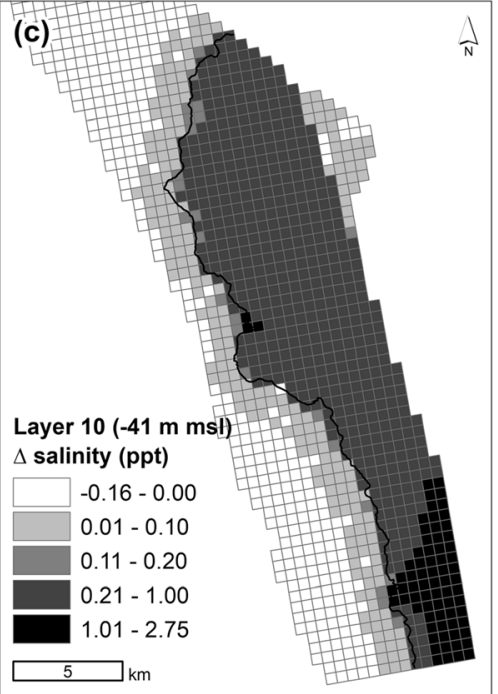

Positive change represents an increase in salinity with sea level rise, while negative change represents a decrease in salinity with sea level rise

condition (section S.3 of the ESM), such an estimate can significantly impact results. There is also an uncertainty regarding the flow condition at such a boundary regarding an assumed vertical flow distribution, considering that the actual hydrogeologic nature of this interflow aquifer boundary is not well understood. In addition, the model did not account for deep offshore freshwater discharge that exists off the coast of Keauhou (Attias et al. 2020).

The model has limitations due to the relatively coarse grid resolution that reduces accuracy of results regarding the spatial distribution of OSDS and LULC. These variables were averaged and assigned as a single lumped value to the corresponding modeling grid since it is certainly impractical to design the grid on an individual OSDS scale. However, numerical accuracy was not impacted by the spatial resolution and mass conservation for water flow and constituent transport was maintained by the model under all applications.

Finally, model calibration is affected by the lack of continuous head records, which is a serious drawback that hinders researchers' efforts in Hawai' $i$ and other similar areas. Available data normally include initial head values measured during the drilling process. Most pumping wells are not continuously monitored, and the initial head measurements were therefore collected at different times. However, the assessment here indicated that the values used for model calibration are within the average fluctuations in water level measurements (section S.1 of the ESM). Fluctuations are not drastic due to the large $K_{\mathrm{h}}$ values associated with volcanic rock materials.

\section{Conclusions}

As is the case for most coastal aquifers, groundwater from West Hawai' $i$ Island is vulnerable to contaminants derived 
from point- and nonpoint-sources such as OSDS, LULC, and WWTP. To ultimately explore local water resource management strategies, this study developed a density-dependent groundwater model for the Keauhou basal aquifer, utilizing multiple measurements and species for calibration. By including head, salinity, $\mathrm{N}$ and $\mathrm{P}$ concentrations, and submarine spring fluxes in the calibration process, this model obtained overall reasonable result ranges. Comparisons between the results from the density-dependent and a freshwater-only model concluded that the former is a better fit to assess nearshore processes. The freshwater-only model overlooks salinity effects on water circulation, and consequently fails to properly simulate nutrient transport. These effects are critical when investigating submarine springs, which provide important freshwater and nutrient supplies to coastal ecosystems that are susceptible to environmental changes. Calibrating the freshwater-only model necessitates the use of an unrealistic $K_{\mathrm{h}}$ due to the failure to account for nearshore flow circulation and the need to define an effective aquifer thickness. As such, in addition to depending on aquifer material-type, $K_{\mathrm{h}}$ is a process-based parameter that depends on model conceptualization and the simulated processes. Despite the extensive data and computation expenses, utilization of a density-dependent model is critical for the accurate assessment of water flow and contaminant transport in a coastal aquifer.

Relative $\mathrm{N}$ source fluxes were estimated from the calibrated model and validated by using $\delta^{15} \mathrm{~N}_{\text {of }} \mathrm{NO}_{3}{ }^{-}$, which is the dominant chemical species in this oxic aquifer. Simulated N was primarily sourced from OSDS and the eastern boundary. Further, $\mathrm{N}$ in submarine springs downgradient of the Kealakehe WWTP were overwhelmingly sourced from the WWTP, as validated by $\delta^{15} \mathrm{~N}$ results. Hence, there is a need to improve on current practices for collecting and treating wastewater and releasing effluents from a single, seemingly inefficient WWTP.

As should be expected, future developments and climate change impact head, salinity, and nutrient concentrations. Specifically, the reduced water flux caused by higher water demands and reduced recharge induced by climate change resulted in declining hydraulic head levels and greater saltwater intrusion. Additionally, contaminant concentrations increased, most prominently around the WWTP. A $1 \mathrm{~m}$ of sea level rise increased hydraulic head by an equivalent amount aquifer wide, but effects on salinity distribution prove to be more complicated. Sea level rise can effectively increase submarine spring flux due to an increase in head gradient.

To further improve the model, a need exists for a better understanding of the eastern boundary structure and assigning its related aquifer interflow. There is also a critical need to identify the range of OSDS $\delta^{15} \mathrm{~N}$, which has proven to vary in isotopic composition. These details have a significant impact on the modeled results, which if used to inform groundwater management without acknowledgement of the various uncertainties, could result in unexpected or undesirable outcomes. Despite the assumptions and limitations, however, it is believed that this model is qualified for use in understanding various water flow and transport processes in the Keauhou coastal aquifer and as a management tool for assessing relative aquifer responses under various management scenarios. In addition to the examples discussed in the study, the model can address others, including OSDS upgrade efforts that include LULC and climate change, as well as the adverse effects in the nearshore environment in response to changes in both quantity and quality of submarine springs. Although this model was developed for a specific aquifer, the methodology and analyses are applicable to various coastal aquifers, where water quantity and quality are of major concern, especially with urban expansion and the increasing severity of climate change-related problems.

Supplementary Information The online version contains supplementary material available at https://doi.org/10.1007/s10040-021-02407-y.

Acknowledgements We would like to express our sincere gratitude to the Kona community for allowing us to conduct this research. We thank Hawai'i County Department of Water Supply, Hawai'i Water Service, Natural Energy Laboratory of Hawai'i Authority, Commission on Water Resource Management, and the Kohanaiki Club for granting us well access to collect groundwater samples. We thank Dr. Kiana Frank, Dr. Sheree Watson, Diamond Tachera, Catherine Hudson, and $\mathrm{Ku}^{\prime} \mathrm{i}$ Keliipuleole for their assistance in the field and with sample analysis. We thank Dr. Delwyn Oki, Dr. Clifford Voss, and Robert Whittier for their discussion and insight regarding model development and results. We also acknowledge Dr. Gregory Chun and Dr. Celia Smith for their input on model conceptualization and Dr. Kostantinos Stamoulis for his input on the LULC scenarios and early model results. This paper was greatly improved by reviews provided by Dr. Nils Moosdorf, Dr. Elco Luijendijk, and two anonymous reviewers. This paper is SOEST Contribution No. 11383 and contributed paper CP-2022-02 of the Water Resources Research Center, University of Hawai' $i$ at Mānoa.

Funding This research was supported by the Hawai' $i$ EPSCoR Program, funded by the National Science Foundation Research Infrastructure Improvement Award (RII) Track-1: 'Ike Wai: Securing Hawai'i's Water Future Award \#OIA-1557349. Parts of this research were also supported by the Department of Earth Sciences (University of Hawai'i) Stearns Award and the Water Resources Research Institute 104b grant program.

\section{Declarations}

Conflict of interest On behalf of all authors, the corresponding author states that there is no conflict of interest.

Open Access This article is licensed under a Creative Commons Attribution 4.0 International License, which permits use, sharing, adaptation, distribution and reproduction in any medium or format, as long as you give appropriate credit to the original author(s) and the source, provide a link to the Creative Commons licence, and indicate if changes were made. The images or other third party material in this article are included in the article's Creative Commons licence, unless indicated otherwise in a credit line to the material. If material is not included in the article's Creative Commons licence and your intended use is not permitted by 
statutory regulation or exceeds the permitted use, you will need to obtain permission directly from the copyright holder. To view a copy of this licence, visit http://creativecommons.org/licenses/by/4.0/.

\section{References}

Abaya LM, Wiegner TN, Colbert SL, Beets JP, Carlson KM, Kramer KL, Most R, Couch CS (2018) A multi-indicator approach for identifying shoreline sewage pollution hotspots adjacent to coral reefs. Mar Pollut Bull 129:70-80. https://doi.org/10.1016/j.marpolbul.2018. 02.005

Alley WM (2006) Tracking U.S. groundwater: reserves for the future? Environ Sci Policy Sustain Dev 48(3):10-25. https://doi.org/10. 3200/ENVT.48.3.10-25

Amato DW, Whittier RB, Dulai H, Smith CM (2020) Algal bioassays detect modeled loading of wastewater-derived nitrogen in coastal waters of O'ahu, Hawai'i. Mar Pollut Bull 150:110668. https://doi. org/10.1016/j.marpolbul.2019.110668

Aquaveo (2021) GMS supported models \& utilities. https://www. aquaveo.com/software/gms-models-utilities. Accessed September 2021

Attias E, Thomas D, Sherman D, Ismail K, Constable S (2020) Marine electrical imaging reveals novel freshwater transport mechanisms in Hawai'i. Sci Adv 6:1-8

Bear J (1972) Dynamics of fluids in porous materials. Elsevier, Amsterdam (reprinted by Dover publications, 1988)

Board of Water Supply (2021) Xeriscape. https://www. boardofwatersupply.com/conservation/xeriscape. Accessed September 2021

Burnett WC, Cable JE, Corbett DR (2003) Radon tracing of submarine groundwater discharge in coastal environments. In: Wang K, Gamo $\mathrm{T}$, Taniguchi $\mathrm{M}$ (eds) Land and marine hydrogeology. Elsevier, Amsterdam, pp 25-43

Cacuci DG (2003) Sensitivity \& uncertainty analysis, vol 1: theory, 1st edn. Chapman and Hall, London. https://doi.org/10.1201/ 9780203498798

Clague DA, Dalrymple GB (1987) The Hawaiian-emperor volcanic chain, part I: geologic evolution. Volcan Hawaii 1(1350):5-54

Commission on Water Resource Management (2019) Water Resources Protection Plan: 2019 update. Department of Land and Natural Resources, State of Hawai'i. https://files.hawaii.gov/dlnr/cwrm/ planning/wrpp2019update/WRPP_ALL_201907.pdf. Accessed September 2021

Delevaux JM, Whittier R, Stamoulis KA, Bremer LL, Jupiter S, Friedlander AM, Poti M, Guannel G, Kurashima N, Winter KB, Toonen R (2018) A linked land-sea modeling framework to inform ridge-to-reef management in high oceanic islands. PLoS One 13(3). https://doi.org/10.1371/journal.pone.0193230

DePaolo DJ, Stolper EM (1996) Models of Hawaiian volcano growth and plume structure: implications of results from the Hawaii scientific drilling project. J Geophys Res Solid Earth 101(B5):11643-11654

Duarte TK, Pongkijvorasin S, Roumasset J, Amato D, Burnett K (2010) Optimal management of a Hawaiian coastal aquifer with nearshore marine ecological interactions. Water Resour Res 46(11). https:// doi.org/10.1029/2010WR009094

Elison-Timm O, Giambelluca TW, Diaz HF (2015) Statistical downscaling of rainfall changes in Hawai' $i$ based on the CMIP5 global model projections. J Geophys Res Atmos 120:92-112. https://doi.org/10. 1002/2014JD022059

El-Kadi AI, Moncur JE (2006) The history of groundwater management and research in Hawaii. Proceedings. http://citeseerx.ist.psu.edu/ viewdoc/download?doi=10.1.1.489.992\&rep=rep1\&type=pdf. Accessed September 2021
El-Kadi AI, Tillery S, Whittier RB, Hagedorn B, Mair A, Ha K, Koh GW (2014) Assessing sustainability of groundwater resources on Jeju Island, South Korea, under climate change, drought, and increased usage. Hydrogeol J 22:625-642. https://doi.org/10.1007/s10040013-1084-y

Engott JA (2011) A Water-budget model and assessment of groundwater recharge for the island of Hawaii. US Geol Surv Sci Invest Rep 2011-5078. https://doi.org/10.3133/sir20115078

Fackrell JK, Glenn CR, Thomas D, Whittier R, Popp BN (2020) Stable isotopes of precipitation and groundwater provide new insight into groundwater recharge and flow in a structurally complex hydrogeologic system: West Hawai'i, USA. Hydrogeol J 28: 1191-1207. https://doi.org/10.1007/s10040-020-02143-9

Ferguson G, Gleeson T (2012) Vulnerability of coastal aquifers to groundwater use and climate change. Nat Clim Chang 2(5):342-345

Flinders AF, Ito G, Garcia MO, Sinton JM, Kauahikaua J, Taylor B (2013) Intrusive dike complexes, cumulate cores, and the extrusive growth of Hawaiian volcanoes. Geophys Res Lett 40:3367-3373. https://doi.org/10.1002/grl.50633

Fukunaga \& Associates, Inc. (2017) Hawaii County Water Use and Development Plan update: Keauhou aquifer system. https://www. hawaiidws.org/wp-content/uploads/2018/06/Combined-Ph-1-2Keauhou-20170510_w-Appendix-final.pdf. Accessed 8 October 2020

Gelhar LW, Welty C, Rehfeldt KR (1992) A critical review of data on field-scale dispersion in aquifers. Water Resour Res 28(7):19551974

Giambelluca TW, Nullet MA, Schroeder TA (1986) Rainfall atlas of Hawai'i: State of Hawai'i, Department of Land and Natural Resources, Division of Water and Land Development, Report $\mathrm{R} 76,267 \mathrm{p}$.

Giambelluca TW, Chen Q, Frazier AG, Price JP, Chen Y-L, Chu P-S, Eischeid JK, Delparte DM (2013) Online rainfall atlas of Hawai'i. Bull Amer Meteor Soc 94:313-316. https://doi.org/10.1175/ BAMS-D-11-00228.1

Gingerich SB, Voss CI (2005) Three-dimensional variable-density flow simulation of a coastal aquifer in southern Oahu, Hawaii, USA. Hydrogeol J 13:436-450. 101007/s10040-004-0371-z. Accessed 14 September 2020

Glenn CR, Whittier RB, Dailer ML, Dulaiova H, El-Kadi AI, Fackrell J, Kelly JL, Waters CA, Sevadjian J (2013) Lahaina groundwater tracer study: Lahaina, Maui, Hawaii. Final report, State of Hawaii Department of Health, Honolulu, HI

Habel S, Fletcher CH, Rotzoll K, El-Kadi AI (2017) Development of a model to simulate groundwater inundation induced by sea-level rise and high tides in Honolulu, Hawaii. Water Res 114:122-134. https://doi.org/10.1016/j.watres.2017.02.035

Harbaugh AW, Banta ER, Hill MC, McDonald MG (2000) MODFLOW2000, the U.S. Geological Survey modular ground-water model; user guide to modularization concepts and the ground-water flow process. US Geol Surv Open-File Rep 00-92, 121 pp

Harris PJ (1995) Water quality impacts from on-site waste disposal systems to coastal areas through groundwater discharge. Environ Geol $26: 262-268$

Hawai'i Climate Change Mitigation and Adaptation Commission (2017) Hawai'i sea level rise vulnerability and adaptation report. Prepared by Tetra Tech, Inc. and the State of Hawai'i Department of Land and Natural Resources, Office of Conservation and Coastal Lands, under the State of Hawai'i Department of Land and Natural Resources Contract no. 64064.https://climateadaptation.hawaii.gov/wpcontent/uploads/2018/01/SLR-Report_-January-2018.pdf. Accessed 30 November 2020

Holzbecher EO (1998) Modeling density-driven flow in porous media: principles, numerics, software. Springer, Heidelberg, Germany

Howarth RW, Marino R (2006) Nitrogen as the limiting nutrient for eutrophication in coastal marine ecosystems: evolving views over 
three decades. Limnol Oceanogr 51(1, part 2):364-376. https://doi. org/10.4319/lo.2006.51.1_part_2.0364

Hunt CD (1996) Geohydrology of the island of Oahu, Hawaii: US Geological Survey Prof Pap 1412-B

Hunt CD (2014) Baseline water-quality sampling to infer nutrient and contaminant sources at Kaloko-Honokohau National Historical Park, Island of Hawai'i, 2009. US Geol Surv Sci Invest Rep 2014$5158,52 \mathrm{pp}$

Hunt CD, Rosa SN (2009) A multitracer approach to detecting wastewater plumes from municipal injection wells in nearshore marine waters at Kihei and Lahaina, Maui, Hawaii. US Geol Surv Sci Invest Rep 2009-5253, 166 pp. http://pubs.usgs.gov/sir/2009/5253/

Izuka SK (2011) Potential effects of roadside dry wells on groundwater quality on the Island of Hawaii: assessment using numerical groundwater models. US Geol Surv Sci Invest Rep 2011-5072, 30 pp

Izuka SK, Engott JA, Rotzoll K, Bassiouni M, Johnson AG, Miller LD, Mair A (2018) Volcanic aquifers of Hawaii: hydrogeology, water budgets, and conceptual models (ver. 2.0, March 2018): US Geol Surv Sci Invest Rep 2015-5164, 158 pp

Johnson AG, Glenn CR, Burnett WC, Peterson RN, Lucey PG (2008) Aerial infrared imaging reveals large nutrient-rich groundwater inputs to the ocean. Geophys Res Lett 35:L15606. https://doi.org/10. 1029/2008GL034574

Juvik JO, Ekern PC (1978) A climatology of mountain fog on Mauna Loa, Hawaii Island. Technical Report, University of Hawaii Water Resources Research Center, Honolulu, HI, p 118, 63 pp

Kauahikaua J, Hildenbrand T, Webring M (2000) Deep magmatic structures of Hawaiian volcanoes, imaged by three-dimensional gravity models. Geology 28(10):883-886

Kelly JL, Dulai H, Glenn CR, Lucey PG (2019) Integration of aerial infrared thermography and in situ radon-222 to investigate submarine groundwater discharge to Pearl Harbor, Hawaii, USA. Limnol Oceanogr 64(1):238-257. https://doi.org/10.1002/lno.11033

Kemper KE (2004) Groundwater: from development to management. Hydrogeol J 12(1):3-5. https://doi.org/10.1007/s10040-003-0305-1

Kendall C, Aravena R (2000) Nitrate isotopes in groundwater systems. In: Cook PG, Herczeg AL (eds) Environmental tracers in subsurface hydrology. Springer, Boston, MA, pp 261-297. https://doi.org/10. 1007/978-1-4615-4557-6 9

Kitanidis PK (1996) On the geostatistical approach to the inverse problem. Adv Water Res 19(6):333-342. https://doi.org/10.1016/03091708(96)00005-X

Knee KL, Layton BA, Street JH, Boehm AB, Paytan A (2008) Sources of nutrients and fecal indicator bacteria to nearshore waters on the north shore of Kaua'i (Hawai'i, USA). Estuar Coasts 31:607-622

Knee KL, Street JH, Grossman EE, Boehm AB, Paytan A (2010) Nutrient inputs to the coastal ocean from submarine groundwater discharge in a groundwater-dominated system: relation to land use (Kona coast, Hawaii, U.S.A.). Limnol Oceanogr 55(3):1105-1122. https://doi. org/10.4319/lo.2010.55.3.1105

Langevin CD, Thorne DT, Jr., Dausman AM, Sukop MC, Guo W (2008) SEAWAT Version 4: a computer program for simulation of multispecies solute and heat transport. US Geological Survey Techniques and Methods book 6, chapter A22, USGS, Reston, VA, 39 pp

Lapointe BE, O'Connell JD, Garrett GS (1990) Nutrient couplings between on-site sewage disposal systems, groundwaters, and nearshore surface waters of the Florida Keys. Biogeochemistry 10(3): 289-307 https://www.jstor.org/stable/1468691

Lau LK, Mink JF (2006) Hydrology of the Hawaiian Islands. University of Hawaii Press, Honolulu, HI

Lee J (2021) pyPCGA. https://github.com/jonghyunharrylee/pyPCGA. Accessed September 2021

Lee J, Kitanidis PK (2014) Large-scale hydraulic tomography and joint inversion of head and tracer data using the principal component geostatistical approach (PCGA). Water Resour Res 50(7):5410 5427. https://doi.org/10.1002/2014WR015483
Lee E, Hyun Y, Lee K-K (2013) Sea level periodic change and its impact on submarine groundwater discharge rate in coastal aquifer. Estuar Coast Shelf Sci 121-122:51-60. https://doi.org/10.1016/j.ecss. 2013.02.011

Lee J, Yoon H, Kitanidis PK, Werth CJ, Valocchi AJ (2016) Scalable subsurface inverse modeling of huge data sets with an application to tracer concentration breakthrough data from magnetic resonance imaging. Water Resour Res 52(7):5213-5231. https://doi.org/10. 1002/2015WR018483

Lee J, Rolle M, Kitanidis PK (2018) Longitudinal dispersion coefficients for numerical modeling of groundwater solute transport in heterogeneous formations. J Contam Hydrol 212:41-54

McKenzie T, Holloway C, Dulai H, Tucker JP, Sugimoto R, Nakajima T, Harada K, Santos IR (2020) Submarine groundwater discharge: a previously undocumented source of contaminants of emerging concern to the coastal ocean (Sydney, Australia). Mar Pollut Bull 160. https://doi.org/10.1016/j.marpolbul.2020.111519

Mezzacapo M, Donohue MJ, Smith C, El-Kadi AI, Falinski K, Lerner DT (2020) Hawai'i's cesspool problem: review and recommendations for water resources and human health. J Contemp Water Res Educ 170:35-75

Moore WS (2010) The effect of submarine groundwater discharge on the ocean. Annu Rev Mar Sci 2:59-88. https://doi.org/10.1146/ annurev-marine-120308-081019

Murgulet D, Tick GR (2016) Effect of variable-density groundwater flow on nitrate flux to coastal waters. Hydrol Process 30(2):302-319. https://doi.org/10.1111/gwat.12020

National Oceanic and Atmospheric Administration (2006) C-CAP Land Cover, Kauai, Hawaii 2005. Coastal change analysis program (CCAP) high-resolution land cover. NOAA Office for Coastal Management, Charleston, SC. https://coast.noaa.gov/htdata/raster1/ landcover/bulkdownload/hires/hi/hi_hawaii_2005_ccap_hr_land_ cover.img. Accessed December 2019

Nichols RJ, Cazenave A (2010) Sea-level rise and its impact on coastal zones. Science 328(5985):1517-1520. https://doi.org/10.1126/ science. 1185782

Oki DS (1999) Geohydrology and numerical simulation of the groundwater flow system of Kona, Island of Hawaii. US Geol Surv Sci Invest Rep 99-4073, 70 pp

Oki DS (2005) Numerical simulation of the effects of low-permeability valley-fill barriers and the redistribution of ground-water withdrawals in the Pearl Harbor area, Oahu, Hawaii. US Geol Surv Sci Invest Rep 2005-5253, $111 \mathrm{pp}$

Pang L, Nokes C, Šimůnek J, Kikkert H, Hector R (2006) Modeling the impact of clustered septic tank systems on groundwater quality. Vadose Zone J 5(2):599-609. https://doi.org/10.2136/vzj2005.0108

Parra SM, Valle-Levinson A, Marino-Tapia I, Enriquez C (2014) Salt intrusion at a submarine spring in a fringing reef lagoon. $\mathrm{J}$ Geophys Res Oceans 120:2736-2750. https://doi.org/10.1002/ 2014JC010459

Patel M, Kumar R, Kishor K, Mlsna T, Pittman CU Jr, Mohan D (2019) Pharmaceuticals of emerging concern in aquatic systems: chemistry, occurrence, effects, and removal methods. Chem Rev 119(6):3510 3673. https://doi.org/10.1021/acs.chemrev.8b00299

Pfeffer WT, Harper JT, O’Need S (2008) Kinematic constraints on glacier contributions to 21 st-century sea-level rise. Science 321:1340 1343. https://doi.org/10.1126/science.1159099

Reay WG (2004) Septic tank impacts on ground water quality and nearshore sediment nutrient flux. Groundwater 42(7):1079-1089. https://doi.org/10.1111/j.1745-6584.2004.tb02645.x

Reilly TE, Franke OL, Bennet GD (1984) The principle of superposition and its application in ground-water hydraulics. US Geol Surv OpenFile Rep 84-459, 36 pp. https://doi.org/10.3133/ofr84459

Richardson CM, Dulai H, Whittier RB (2017) Sources and spatial variability of groundwater-delivered nutrients in Maunalua Bay, O'ahu, 
Hawai'i. J Hydrol Reg Stud 11:178-193. https://doi.org/10.1016/j. ejrh.2015.11.006

Rotzoll K, El-Kadi AI (2008) Estimating hydraulic conductivity from specific capacity for Hawaii aquifers, USA. Hydrogeol J 16(5): 969-979. https://doi.org/10.1007/s10040-007-0271-0

Schulze-Makuch D (2005) Longitudinal dispersivity data and implications for scaling behavior. Groundwater 43(3):443-456

Shuler CK, El-Kadi AI, Dulai H, Glenn CR, Fackrell J (2017) Source partitioning of anthropogenic groundwater nitrogen in a mixed-use landscape, Tutuila, American Samoa. Hydrogeol J 25(8):2419 2434. https://doi.org/10.1007/s10040-017-1617-x

Souza WR, Voss CI (1987) Analysis of an anisotropic coastal aquifer system using variable-density flow and solute transport simulation. J Hydrol 92(1-2):17-41. https://doi.org/10.1016/0022-1694(87) 90087-4

State of Hawai'i (2021) Hawai'i Statewide GIS Program. http://planning. hawaii.gov/gis/. Accessed September 2021

Street JH, Knee KL, Grossman EE, Paytan A (2008) Submarine groundwater discharge and nutrient addition to the coastal zone and coral reefs of leeward Hawai'i. Mar Chem 109(3-4):355-376. https://doi. org/10.1016/j.marchem.2007.08.009

Swenson HA and Baldwin HL (1965) A primer on water quality. US Department of the Interior Geological Survey, Washington, DC. https://doi.org/10.3133/7000057

Tachera D (2021) Groundwater chemistry: nutrient data. HydroShare. https://doi.org/10.4211/hs.d812bbb7c93348999371c9f1 f517297f

Taniguchi M, Burnett WC, Cable JE, Turner JV (2002) Investigation of submarine groundwater discharge. Hydrol Process 16:2115-2129. https://doi.org/10.1002/hyp.1145

Taniguchi M, Dulai H, Burnett KM, Santos IR, Sugimoto R, Stieglitz T, Kim G, Moosdorf N, Burnett WC (2019) Submarine groundwater discharge: updates on its measurement techniques, geophysical drivers, magnitudes, and effects. Front Environ Sci 7:141. https:// doi.org/10.3389/fenvs.2019.00141

Thomas DM, Paillet FL, Conrad ME (1996) Hydrogeology of the Hawaii Scientific Drilling Project borehole KP-1 2: groundwater geochemistry and regional flow patterns. J Geophys Res 101(B5):1168311694. https://doi.org/10.1029/95JB03845

US Geological Survey (2006) A GAP analysis of Hawaii. US Geological Survey, The Hawaii GAP Analysis Project. http://gapanalysis.nbii. gov/portal/community/GAP_Analysis_Program/Communities/ GAP Home/. Accessed September 2021

US Geological Survey (2021) Water resources of the United States. https://water.usgs.gov/software/lists. Accessed September 2021

Voss CI, Souza WR (1987) Variable density flow and solute transport simulation of regional aquifers containing a narrow freshwater- saltwater transition zone. Water Resour Res 23(10):1851-1866. https://doi.org/10.1029/WR023i010p01851

Voss CI, Souza WR (1998) Dynamics of a regional freshwater-saltwater transition zone in an anisotropic coastal aquifer system. US Geol Surv Open-File Rep 98-398

Walter DA (2008) Use of numerical models to simulate transport of sewage-derived nitrate in a coastal aquifer, central and Western Cape Cod, Massachusetts. US Geol Surv Sci Invest Rep $2007-$ 5359. https://pubs.usgs.gov/sir/2007/5259/. Accessed 12 September 2020

Werner AD, Simmons CT (2009) Impact of sea-level rise on seawater intrusion in coastal aquifer. Ground water 47(2):197-204. https:// doi.org/10.1111/j.1745-6584.2008.00535.X

Whittier RB, El-Kadi AI (2009) Human and environmental risk ranking of onsite sewage disposal systems for Oahu. Final Rep Prep State Hawaii Dep Health Safe Drink Water Branch. https:/health.hawaii. gov/wastewater/files/2015/09/OSDS_OAHU.pdf. Accessed 16 December 2020

Whittier RB, El-Kadi AI (2014) Human health and environmental risk ranking of on-site sewage disposal systems for the Hawaiian Islands of Kauai, Molokai, and Hawaii. Final report, State Hawaii Dept. Health, Safe Drinking Water Branch. https://health.hawaii.gov/ wastewater/files/2015/09/OSDS NI.pdf. Accessed 25 September 2020

Wiegner TN, Mokiao-Lee AU, Johnson EE (2016) Identifying nitrogen sources to thermal tide pools in Kapoho, Hawai'i, U.S.A., using a multi-stable isotope approach. Mar Pollut Bull 103:63-71. https:// doi.org/10.1016/j.marpolbul.2015.12.046

Wilson Okamoto Corporation (2019) Kealakehe Wastewater Treatment Plant R-1 Upgrade Draft Environmental Impact Statement. http:// oeqc2.doh.hawaii.gov/EA EIS Library/2019-02-23-HA-DEISKealakehe-WWTP-R1-Upgrade.pdf. Accessed 15 September 2020

Wolfe EW, Wise WS, Dalrymple GB (1997) The geology and petrology of Mauna Kea Volcano, Hawaii: a study of postshield volcanism. US Geol Surv Prof Pap 1557

Yee JJS (1987) Hawaii ground-water quality. US Geol Surv Open-File Rep 87-0721

Zheng C, Wang PW (1999) MT3DMS; a modular three-dimensional multispecies transport model for simulation of advection, dispersion, and chemical reactions of contaminants in groundwater systems; documentation and user's guide. Engineer Research and Development Center contract report SERDP-99-1, US Army Corps of Engineers, Washington DC, 221 pp

Publisher's note Springer Nature remains neutral with regard to jurisdictional claims in published maps and institutional affiliations. 